\title{
From Convergence to Divergence: Portuguese Economic Growth, 1527-1850
}

DOI:

$10.1017 /$ S0022050719000056

\section{Document Version}

Accepted author manuscript

Link to publication record in Manchester Research Explorer

\section{Citation for published version (APA):}

Palma, N., \& Reis, J. (2019). From Convergence to Divergence: Portuguese Economic Growth, 1527-1850. Journal of Economic History, 79(2), 477-506. https://doi.org/10.1017/S0022050719000056

\section{Published in:}

Journal of Economic History

\section{Citing this paper}

Please note that where the full-text provided on Manchester Research Explorer is the Author Accepted Manuscript or Proof version this may differ from the final Published version. If citing, it is advised that you check and use the publisher's definitive version.

\section{General rights}

Copyright and moral rights for the publications made accessible in the Research Explorer are retained by the authors and/or other copyright owners and it is a condition of accessing publications that users recognise and abide by the legal requirements associated with these rights.

\section{Takedown policy}

If you believe that this document breaches copyright please refer to the University of Manchester's Takedown Procedures [http://man.ac.uk/04Y6Bo] or contact uml.scholarlycommunications@manchester.ac.uk providing relevant details, so we can investigate your claim.

\section{OPEN ACCESS}




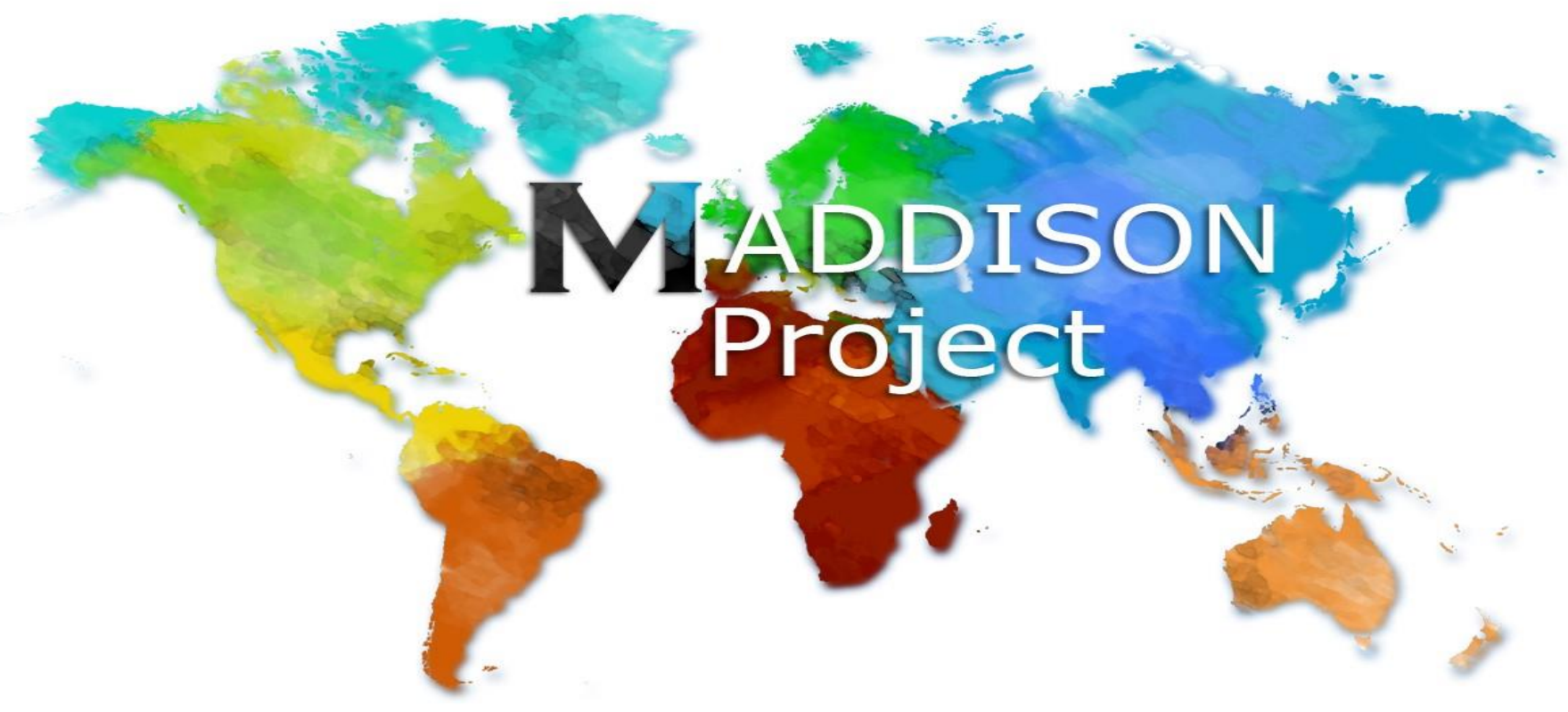

\section{The Maddison Project}

From Convergence to Divergence:

Portuguese Economic Growth, 1527-1850

Maddison-Project Working Paper WP-11

Nuno Palma and Jaime Reis

May 2018 


\title{
From CONVERGENCE TO DiverGenCE: PorTuguese ECONOMIC GroWTH, 1527-1850
}

\author{
Nuno Palma \\ Department of Economics, University of Manchester and CEPR \\ Jaime Reis \\ Instituto de Ciências Sociais, Universidade de Lisboa
}

\begin{abstract}
We construct the first time-series for Portugal's per capita GDP for 1527-1850, drawing on a new and extensive database. Starting in the early 1630 s there was a highly persistent upward trend which accelerated after 1710 and peaked 40 years later. At that point, per capita income was high by European standards, though behind the most advanced Western European economies. But as the second half of the eighteenth century unfolded, a phase of economic decline was initiated. This continued into the nineteenth century, and over the long-run there was no per capita growth: by 1850 per capita incomes were not different from what they had been in the early 1530s. As a result, Portugal found itself as one of the most backward European economies precisely at the dawn of the era of modern economic growth.
\end{abstract}

Keywords: Early Modern Portugal, Historical National Accounts, Standards of Living Debate, The Little Divergence, Malthusian Model

JEL codes: N 13, O52

\footnotetext{
${ }^{1}$ We are grateful to Steve Broadberry, Leonor F. Costa, António C. Henriques, Kivanç Karaman, Wolfgang Keller, Cormac Ó Gráda, Șevket Pamuk, Leandro Prados de la Escosura, Joan R. Rosés, Jacob Weisdorf, Jeffrey Williamson, and many participants at the Nova SBE lunchtime seminar, the 2014 Accounting for the Great Divergence conference, The University of Warwick in Venice, the 2014 APHES conference in Lisbon, and the 2015 EHES in Pisa for discussion of this paper. We also thank colleagues on the Prices, Wages and Rents in Portugal 1300-1910 project. This paper partly relies on joint work with Leonor Costa and Conceição Andrade Martins, to whom we owe special thanks. We are also grateful to Bruno Lopes, Carlos Faísca, Fátima Farrica, Ricardo Pereira and Paulo Paixão Silva for dedicated research assistance. Finally, we thank Fundação para a Ciência e a Tecnologia for financial support.
} 


\section{Introduction}

Thomas and McCloskey (1981, p.102) describe Portugal, along with Spain, as the "giants" of the sixteenth century, especially in comparison with Britain, the "inconsiderable little island of the sixteenth century, a mere dwarf". In turn, Bairoch (1976, p. 286) considered Portugal one of Europe's five richest countries as late as 1800. Bairoch et al (1980) also placed Lisbon as one of Europe's four most populous cities (after Naples, Paris and London). Despite this promising start, Portugal became one of Europe's poorest countries during the second half of the nineteenth century, and its convergence only started with the emergence of modern economic growth in the 1950 s (Lopes 2004).

In this paper, we rely on new archival data to construct the first time-series for Portugal's per capita GDP for 1527-1850. We show that Portugal's early modern performance since 1527 was characterized by several distinctive phases. The first was a period of five decades of intensive growth which lasted from the late 1520 s to the late 1570 s. This was followed by decline which lasted until the 1630s. From then until the mid-eighteenth century the economy grew steadily, both in terms of incomes per capita and population, except for a 20-year interval between 1690-1710. As a result, Portugal's 1750s per capita GDP was rather high by European comparison, though still firmly below that of England or the Netherlands. ${ }^{2}$

Once past the 1750s, however, the sources of this expansion began to peter out. Economic performance slowed down but population grew strongly, and within half a century all of the recent GDP per capita and real wage gains were wiped out. ${ }^{3}$ Thereafter income per person continued to decline, with the consequence that by the middle of the nineteenth century Portugal became one of the most backward economies of Europe, precisely as the era of modern economic growth was beginning in other countries. ${ }^{4}$ Over the long-run, there was no per capita growth: by 1850 per capita incomes were not different from what they had been in the early 1530s.

In the spirit of Broadberry et al (2015) or van Zanden and van Leeuwen (2012), who focus on proximate rather than fundamental causes of growth, our goal in this paper is to provide a factual description of Portugal's macroeconomic history. So while we provide a detailed national accounting exercise regarding Portugal's early modern economy, we leave for future work the explanations for the fundamental causes which explain the long-term dynamics of Portugal's economy - and in particular, the reasons underlying the remarkable reversion which occurred since the mid-eighteenth century.

\section{Our new data}

In this section we discuss the data employed in this article to construct the macroeconomic variables required by our analysis. Our aim is to obtain long-term annual series for population and occupational shares, wages, agricultural and manufacturing price indices, and land rents. These are then combined to generate a number of analytic tools such as real wages,

\footnotetext{
${ }^{2}$ In the 120-year period between 1630 and the peak of 1754, Portugal's real per capita income grew by an average of $0.54 \%$ per year - a remarkable rate for a pre-modern economy.

${ }^{3}$ In the five decades following 1750 , population grew at an annual rate of increase of $0.34 \%$ - and thus contributed significantly to the erosion of real per capita incomes.

${ }^{4}$ Around 1850 Portugal's real per capita GDP was below that of other countries of the European periphery such as Denmark, Norway, Sweden, Finland and Spain (Reis 2000).
} 
GDP and GDP per capita. The basic procedures followed are standard in the early modern macroeconomic literature. ${ }^{5}$

\subsection{Factor and output prices}

A critical component for this research consists of long-term annual series for the following variables: population, wages, agricultural and manufacturing prices, and land rents. In this section, we focus only on the methodology employed for gathering prices, wages and rents, following as far as possible that employed in similar studies. This has been carried out in the framework of a recent major research project, "PWR- Prices, wages and rents in Portugal, 1300-1910", which supports the present work. ${ }^{6}$

The data we have collected originates in the four macro-regions of the country. These correspond to: the North represented by Porto and its hinterland; the Centre represented by Coimbra and its hinterland; Lisbon and its hinterland; and the South represented by Évora and its hinterland. Figure 1 shows a map of the country, including its six provinces, its main cities and all the lesser locations mentioned in this paper. The prices collected here have been put together in accordance with the criteria normally adopted in these studies. ${ }^{7}$

Several concerns have guided our options regarding how these raw data should be collected and processed. One is that they should reflect market values. To this end, we try to avoid distorting influences on our figures such as administered prices or subsidies, which were common in this period. A second one is that we should avoid using too many sources. In this way we help reduce the likelihood of confusing variation in the accounting procedures. A third is to give preference to sources which would yield long and continuous series. This keeps down as far as possible the use of interpolation and proxying for missing observations. ${ }^{8}$ We achieve this by selecting organizations whose archives belong to sectors which fit the following description: local government, royal administration, hospitals, prisons, the royal university of Coimbra, charities, orphanages, and the Church, particularly monasteries and convents. Within these, we have been able to identify institutions which lasted uninterruptedly for centuries, kept well-organized accounts continuously, and imposed internal auditing procedures. They were also highly engaged in the market economy and therefore generated a considerable amount of high-frequency information.

Like the rest of early modern Europe, Portugal's system of measurement of commodities, be they liquid, solid or linear, showed considerable variation within the country. To convert these raw statistics into quantities which could be used for national estimates, we had to normalize them according to the metric system. ${ }^{9}$ For example, the almude, a measure of liquids, contained in Lisbon 16.8 liters, in Porto 25.4 liters, in Coimbra 16.7 liters and in Évora 17.4 liters. Non-metric measures for the same commodity also proliferated: Charcoal in Lisbon, for instance, was sold in five different units.

\footnotetext{
${ }^{5}$ Fouquet and Broadberry (2015) provide an overview of these methods.

${ }^{6}$ All the basic data has been released to the public at http://pwr-portugal.ics.ul.pt/?page_id=56 and also listed at the Global Price and Income History Group of UC-Davis, available at: http://gpih.ucdavis.edu/Datafilelist.htm. In the appendix to this paper, we give the full list of al primary sources consulted.

7 For a detailed discussion, see for example Pamuk and Ozmucur (2002).

${ }^{8}$ We show the percentage of the variation of the principal data that is covered by our sources in Table A1 of the online Appendix. In some cases, we proxied the price of a good (e.g. beef) for a missing year by that of a close substitute (e.g. pork) by using price proportionality from a nearby year for which we had both prices.

${ }^{9}$ Portugal had a single monetary unit, the real, whose official value in silver shifted from time to time.
} 


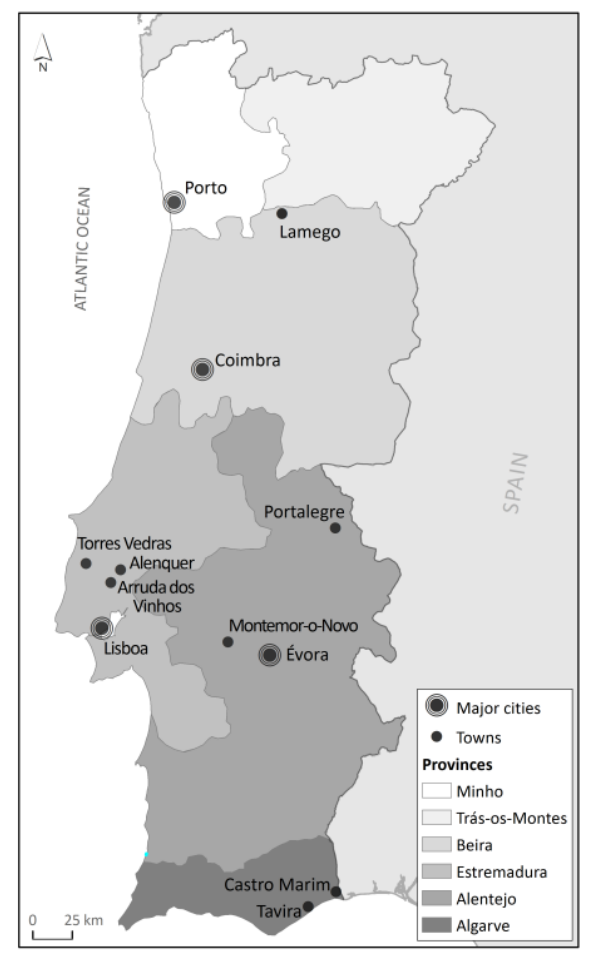

Figure 1. Map of Portugal. The borders correspond to the $18^{\text {th }}$ century provinces, and the map indicates locations referred to in this paper.

As far as prices are concerned, we have selected those corresponding to the principal articles of consumption and production. Consumables include wheat and maize bread, meat, olive oil, wine, eggs and hens, all of which, in the literature of the early modern period, form part of the widely accepted standard consumption basket. From the production side, we take the prices of charcoal, linen cloth, soap and candles. We represent the cost of labor by means of a weighted wage consisting of both skilled and unskilled male adult workers. For the former, we use the wages of masons, taking care to exclude those of master masons. As for the latter, we use the wages of helpers (servidores, serventes, serviçais, trabalhadores) which capture the value of raw labor under well identified categories which avoid distortions caused by variation in the unidentified presence of human capital in the labor stock. These wages always refer to employment in either agriculture or the building industry and to situations in which nonmonetary complementary remunerations were absent.

Land rents have attracted little attention from the economic historians of this period in Portugal. In fact, rents are important for the present narrative as indicators of the value of the services produced by land and as an indicator of its relative scarcity. At this time, most land in use was not directly cultivated by its lords. Possibly a little less than half of all agricultural land was rented out on terms of commercial tenancy, with leases typically running from three to ten years (Monteiro 2005). The remainder was held under long term or perpetual emphyteutic contracts, whereby the lord received a fixed fee and the tenant enjoyed a de facto assignable right to the exclusive enjoyment of all the fruits of the land (Costa et al 2016; Fonseca and Reis 2011). ${ }^{10}$ We assume that the rent of the first category of contracts provides a reliable indication of the market value of all agricultural land per hectare. Data for land rents are currently not abundant. We value them by means of an indicator based on the aggregate

${ }^{10}$ While the first of these arrangements was employed mostly for larger units of production, the latter corresponded to small or minuscule farms. 
rent of a time-invariant set of thirty-two estates owned and regularly leased by a charitable institution in Alentejo (Santos 2003). Since this only covers the years from 1595 to 1850, we fill in the rest of the sixteenth century from other comparable sources. ${ }^{11}$

\subsection{Population, occupational distribution and structural change}

Palma et al. (2017) have constructed the first annual series for Portugal's population for 1527-1850, using a combination of stocks from population counts and censuses, and flows from the parish registers of several dozen parishes. Their estimation is inspired by the seminal work on England by Wrigley and Schofield (2010/1989) and Wrigley et al (1997), but offers a number of advantages over their exercise. Coverage is more complete due to the uniformity and monitoring imposed by the Catholic Church, and to the availability of several national premodern censuses.

We now discuss in detail the characteristics of Portugal's occupational distribution and structural change over this period. ${ }^{12}$ The first step is to estimate urban population, and the main economic activities in which the population was engaged. We split the population between the agricultural and the non-agricultural sectors. ${ }^{13} \mathrm{~A}$ continuous occupational structure time series is not available at present and it is unlikely to become so in the near future. We rely on a set of evenly spaced benchmarks linked by means of linear interpolation. We start in 1500 and continue at 50-year intervals all the way down to 1850 . Our categorization does no more than distinguish between the two most basic economic sectors - agriculture and nonagriculture - since we lack consistent information to allow for a more detailed analysis.

We are unable to consider the active population separately from the rest of the population. Our quantification refers therefore to the aggregate population of families dependent on a particular economic activity, without regard to whether their individual members were employed full-time, part-time or not working at all. We should note that the historical sources we employ, in particular tax records, are also organized on a family basis, never on an individual one, and mention only the occupation of the heads of households.

Table 1 displays the best available figures for Portugal's urban population, defined as the total number of inhabitants of agglomerations of more than 5,000 residents. We employ one source only, Bairoch (1988) - but we make an adjustment to it. ${ }^{14}$ Bairoch included in his estimate all urban centers designed as such by his sources, irrespective of size, and simply added them up to obtain "urban population". We exclude from the category of "urban" all towns having less than 5,000 inhabitants. At the same time, we have recovered the residents of all the towns that Bairoch dropped from his count every time they were not mentioned in his sources for a particular benchmark, though they are known to have continued to exist over this period. When this happens, we assume that it was due to an error or omission, and not to a contraction of the population in question to a figure below our stipulated minimum. We have therefore interpolated the "missing" inhabitants at the level observed in the count of the previous benchmark, as long as this was not less than 5,000 inhabitants.

\footnotetext{
${ }^{11}$ For details, see Reis (2016).

12 This section updates the discussion in the online Appendix to Costa et al. (2015).

${ }^{13}$ Evidently, the rural and urban non-agricultural components both encompass manufacturing, transport, trade and administrative activities wherever carried out, but because of lack of information, we are unable to consider these distinctions.

${ }^{14}$ For different reasons, Álvarez-Nogal and Prados de la Escosura (2007) employ data for Spain which also departs from Bairoch's. Our correction is smaller than theirs, however.
} 


\begin{tabular}{cccccc}
\hline & $(1)$ & $(2)$ & $(3)$ & $(4)$ & $(5)$ \\
\hline total & urban & $\begin{array}{c}\text { rural non } \\
\text { agricultural }\end{array}$ & agricultural & $\begin{array}{c}\text { total non- } \\
\text { agricultural }\end{array}$ \\
\hline 1500 & 1 & 0.155 & 0.169 & 0.676 & 0.324 \\
\hline 1550 & 1.275 & 0.193 & $0.205^{*}$ & 0.877 & 0.398 \\
\hline 1600 & 1.837 & 0.242 & $0.318^{*}$ & 1.277 & 0.560 \\
\hline 1650 & 2.148 & 0.267 & $0.512^{*}$ & 1.369 & 0.779 \\
\hline 1700 & 2.349 & 0.293 & $0.672^{*} *$ & 1.384 & 0.965 \\
\hline 1750 & 2.475 & 0.429 & $0.721^{* * *}$ & 1.325 & 1.150 \\
\hline 1800 & 2.936 & 0.476 & $0.848^{* * *}$ & 1.612 & 1.324 \\
\hline 1850 & 3.455 & 0.607 & $0.537^{* * * * *}$ & 2.311 & 1.144 \\
\hline
\end{tabular}

Table 1. Portugal's population: total and by sector (millions). Sources: for col. 1, 1500 from Rodrigues (2008, p.176), and other dates from Palma et al. (2017); col. 2 from Bairoch (1988) revised; * is a linear interpolation based on Álvarez-Nogal and Prados dela Escosura (2007); ** is from Montemor-o-Novo, Portalegre, Castro Marim and Tavira-Cacela's archival data; *** inferred from Sá (2005); ***** is from Reis (2005).

The remaining columns of Table 1 show rural non-agricultural, agricultural and total non-agricultural population. To arrive at these figures, our reasoning starts with the observation that only a small part of the agricultural labor force in Europe lived in urban units with a population of more than 5,000 and thus represented a very small proportion of the total urban population (Allen 2000, Van Zanden 2005). These authors have assumed therefore, as a reasonable simplification, that in practice this segment can be represented as equal to zero. ${ }^{15}$ We follow the same assumption here.

The next task is to arrive at the share of the non-urban population that was engaged in agriculture and was ipso facto the "agricultural population" of the country. For 1500, we endorse the assumption that the occupational structure in Europe, up to the early-sixteenth century, was roughly homogeneous and that agriculture occupied about 80 percent of the rural population (Wrigley 1985, Allen 2000). The remaining 20 percent corresponded to the rural non-agricultural population. ${ }^{16}$ At the end of our period, we have reliable data from Sá (2005) for 1750 , and from Reis (2005) for 1800 and 1850 .

We have also constructed a 1700 benchmark, which is based on tax rolls compiled around this date, and held at present in their respective municipal archives. ${ }^{17}$ They contain detailed, reliable information on occupations of heads of families. They pertain to rural townships (i.e. with less than 5,000 inhabitants) and their respective hinterlands. Two of them (Montemor-o-Novo and Portalegre) are in Alentejo. This was a lightly populated, predominantly rural province in the south, with some "agro-towns", and as such was not particularly representative of the country as a whole. The other two cases come from the province of Al-

\footnotetext{
${ }^{15}$ More recently, Álvarez Nogal and Prados de la Escosura (2007) claimed that, in the case of Spain's urban network, there was a significant presence of "agro-towns". This would invalidate this assumption and has led to a much more complicated treatment of the data, so as to separate the "urban agricultural" component. In the case of Portugal, we have chosen to ignore this problem since the only region - Alentejo - where agro-towns were present represented a small proportion of the national population. We therefore accept that the urban population as defined was non-agricultural population.

${ }_{16}$ These proportions are confirmed by the available evidence for late-medieval Portugal. According to Godinho (1968-72), in Alenquer, a provincial center, at the end of the fifteenth century those engaged in agriculture represented $74 \%$ of the entire population. In the case of Torres Vedras, a small town and its hinterland, in 1381, the "non-agricultural population" came to $33 \%$ of the whole (Rodrigues 1995). Further back, in 1369, in Arruda dos Vinhos, near Lisbon, $86 \%$ of all households were of farmers, the non-agricultural population representing therefore 14\% (Marques 1980, p. 126-31).

${ }^{17}$ For a discussion of these tax rolls, see Reis (2017).
} 
garve (Castro Marim and Tavira-Cacela), a coastal region further south, with a higher density of population, many small holders and a complete absence of "agro-towns". Altogether, it would have been much more like the rest of the country north of Lisbon. ${ }^{18}$ Despite the differences between these two regions, in 1700 their respective shares of non-urban population engaged in agriculture were very similar. They were within a narrow band from 64 to $67 \%$. Pending fresh evidence from additional sources, we have opted for the mean value of $65.5 \%$. The remaining benchmarks - 1550, 1600 and 1650 - are derived by means of a log-linear interpolation as used by Álvarez-Nogal and Prados de la Escosura (2007) for Spain for the same years. ${ }^{19}$

In Table 2, we present the absolute values of Table 1 converted into shares of total population. The advantage of this lies in allowing us to perceive, at a glance, the shifts in categories in the socio-economic population categories and thus grasp structural change over time more readily. It suggests, for instance, that the imperial expansion of the sixteenth century did not a have significant impact on the economic weight of agriculture (col.3; Costa et al. 2015; Palma 2016) though, in contrast, it did so during a good part of the eighteenth century's colonial expansion in Brazil. It also brings to light the fact that the higher productivity of secondary and tertiary sectors (col. 4) gained ground for two and a half centuries from 1500 to 1750 , but slowed their contribution to economic modernization after that date. It reveals the apparently steady ruralization of manufacturing activity during the two first centuries considered here and its re-urbanization in the course of the following 150 years (col.5).

\begin{tabular}{cccccc}
\hline & $(1)$ & $(2)$ & $(3)$ & $(4)=(1)+(2)$ & $(5)=(1) /(4)$ \\
\hline 1500 & 0.155 & $\begin{array}{c}\text { Rural non } \\
\text { agricultural }\end{array}$ & Agricultural & $\begin{array}{c}\text { Total non- } \\
\text { agricultural }\end{array}$ & $\begin{array}{c}\text { Urban/ total non- } \\
\text { agricultural }\end{array}$ \\
\hline 1550 & 0.151 & 0.169 & 0.676 & 0.324 & 0.479 \\
\hline 1600 & 0.132 & 0.173 & 0.688 & 0.312 & 0.485 \\
\hline 1650 & 0.124 & 0.239 & 0.695 & 0.305 & 0.432 \\
\hline 1700 & 0.125 & 0.286 & 0.589 & 0.411 & 0.343 \\
\hline 1750 & 0.173 & 0.291 & 0.535 & 0.465 & 0.304 \\
\hline 1800 & 0.162 & 0.289 & 0.549 & 0.451 & 0.373 \\
\hline 1850 & 0.176 & 0.155 & 0.669 & 0.331 & 0.359 \\
\hline
\end{tabular}

Table 2. Portugal: Population shares of total by occupation. Sources: same as for Table 1; urban corresponds to pop. $>5,000$.

\section{Portugal's GDP per capita, 1527-1850}

The early modern economic history literature has embraced the real wage as a valuable measure for international and inter-temporal assessments of living standards (Allen 2003, Pfister et al 2012). On the other hand, a real wage trend suggesting long run stagnation does not necessarily mean that this will be the case for per capita income. In the well-studied Eng-

\footnotetext{
18 The chief town in the county of Montemor-o-Novo had a population of about 3,500 out of a total of 7,300 for both the town and its hinterland (Fonseca 1986). In Castro Marim, these figures were 632 and 1,928, while in Tavira-Cacela they were 1,848 and 2,660. Their agricultural populations were 64 and $67 \%$ respectively (we include 74 fishermen in Tavira, an important fishing port, and treat "agriculture" here as the "primary sector"). In Portalegre, a town of about 7,500 inhabitants ( 1480 households), had a rural hinterland of about 5,000, where $78 \%$ of the population was engaged in agriculture. In the town itself, between 20 and $30 \%$ of the labor force was also agricultural. In all these cases we have treated the usually fairly substantial category of individuals with a "nonidentified occupation" as belonging to the category of those living off agriculture.

19 This interpolation is a better solution than those used by Wrigley and Allen who were obliged to cover, in this manner, two and a half centuries (1550 to 1800) instead of one and a half, as here (1550 to 1700).
} 
lish case, for instance, real day wages conform to such a picture of stagnation during the entire early modern period (Allen 2001, Clark 2007, 2010), yet this is not confirmed by output-side GDP estimates, which show substantial intensive growth (Broadberry et al 2015). When real wages are annual, rather than daily, they confirm the per capita GDP picture (Humphries and Weisdorf 2017).

This points towards a recognition that GDP per capita should be preferred as a measure of overall well-being. In the literature, two ways have been employed for estimating this metric in the case of premodern economies. One is supply-side based, requires abundant production data, and has been employed in the cases of England/GB and the Netherlands (Broadberry et al 2015; Van Zanden and Van Leuween 2012). In countries like Portugal, however, where output data are scarce, one has to rely on demand-based methods as has been done in the cases of Spain, Italy, Sweden and Germany (Álvarez-Nogal and Prados de la Escosura 2013, Malanima 2011, Schön and Krantz 2012, Pfister 2011). The latter consists of two stages. In the first, it has been generally assumed, unrealistically, that all workers were employed the same number of days per year in each year considered. Álvarez-Nogal and Prados de la Escosura (2013) improve on this first step by considering that agricultural output was derived from not only labor but also land. In the present instance, we go further by using supply-side evidence in order to also adjust the labor supply, thus correcting the demand-side estimates for agricultural output.

The second stage is to gauge the size of the non-agricultural sector. This is done either by assuming a constant inter-sectoral productivity gap, which is the baseline option we take here; or by extrapolating the coefficients of a regression using urbanization as a covariate for data pertaining to a later period (Malanima 2011); or through the construction sectorial current-price indexes (Álvarez-Nogal and Prados de la Escosura (2013). We show the results under all three aaproaches. We now present different series which build towards our baseline real per capita GDP. We show all the main results along the way, with additional data being described in the Appendix. We start by displaying our weighted real day wage based on occupational shares. We then transform it into a better measure of annual earnings from income through an adjustment to the number of days worked. This is then used in the construction of agricultural GDP. Finally, we show overall GDP.

\subsection{Real day wages}

To obtain real wages for Portugal, we use data for four regions of the country. We use data for Porto and its hinterland to represent the North (Minho plus Trás-os-Montes in Figure 1), Coimbra and its hinterland to represent the Centre (Beira in Figure 1), Lisbon and its hinterland (Estremadura in Figure 1) and Évora and its hinterland to represent the South (Alentejo plus Algarve in Figure 1).

We convert nominal wages by employing the procedure originally outlined by Allen (2001). We use a CPI defined by the silver price of a basket with a composition of goods assumed to represent the consumption needs of a pre-modern 'respectable' working class family. We make some adaptations to this formula, as required by differences in preferences and geography, whilst taking care that the caloric and protein standards are not significantly altered. ${ }^{20}$ The most important is that dictated by the remarkable shift in bread consumption from wheat to maize (i.e. American corn, zea mays) flour which occurred during the period of this study.

\footnotetext{
${ }^{20}$ Reis (2016) shows that this basket has a similar caloric and protein content as the Strasbourg basket. In the case of fuel consumption, the reduction from 5 to 2 million BTUs per basket is due to the significant difference in average temperatures, from $15.15^{\circ} \mathrm{C}$ in Portugal, compared with $10.25{ }^{\circ} \mathrm{C}$ in Strasbourg or $8.5^{\circ} \mathrm{C}$ in England.
} 
This is taken into account by altering the annual grain content of the CPI in accordance with the information on production shares based on tithes (Oliveira 1990, 2002). ${ }^{21}$ Other changes to the original basket are the replacement of beer by wine, butter by olive oil, and cheese by hens (Table 3).

\begin{tabular}{cccc}
\hline & $\begin{array}{c}\text { Quantity per person } \\
\text { per year } \\
\text { (Strasbourg) }\end{array}$ & $\begin{array}{c}\text { Quantity per person } \\
\text { per year } \\
\text { (Portugal) }\end{array}$ & $\begin{array}{c}\text { Spending share } \\
(\%)\end{array}$ \\
\hline Bread & $182 \mathrm{~kg}$ & $182 \mathrm{~kg}$ & 30.4 \\
\hline Beans/peas & 52 liter & $\begin{array}{c}\text { Substituted by } 52 \\
\text { liters of wheat }\end{array}$ & 6.0 \\
\hline Meat & $26 \mathrm{~kg}$ & $26 \mathrm{~kg}$ & 13.9 \\
\hline Butter & $5.2 \mathrm{~kg}$ & $\begin{array}{c}\text { Substituted by } 5.2 \\
\text { liters of olive oil }\end{array}$ & 4.3 \\
\hline Cheese & $5.2 \mathrm{~kg}$ & Substituted by 5 hens & 3.6 \\
\hline Eggs & $52 \mathrm{units}$ & 52 units & 1.3 \\
\hline Beer & 182 liters & $\begin{array}{c}\text { Substituted by } 68.25 \\
\text { liters of wine }\end{array}$ & 20.6 \\
\hline Soap & $2.6 \mathrm{~kg}$ & $2.6 \mathrm{~kg}$ & 1.8 \\
\hline Linen & $5 \mathrm{~m}$ & $5 \mathrm{~m}$ & 3.3 \\
\hline Candles & $2.6 \mathrm{~kg}$ & $2.6 \mathrm{~kg}$ & 4.7 \\
\hline Lamp oil & 2.6 liter & 2.6 liter & 5.0 \\
\hline Fuel & $5.0 \mathrm{millions}$ of BTU & Substituted by 2 mil- \\
lions of BTU & 100 \\
\hline Total & & & \\
\hline
\end{tabular}

Table 3. Respectability baskets. Source for the Strasbourg basket: Allen (2001, p. 421).

Although we do not have as much data for other parts of the country as we do for Lisbon - and we lack region-specific occupational data altogether - we do have enough data such that for most periods variation is annual for the four regions. As Figure 2 shows, prices move closely together in the four regions, which we interpret as evidence for market integration. It is hence not surprising that wages also exhibit similar trends though the labor market seems less integrated than the commodity market (Figure 3). ${ }^{22}$

21 This procedure mitigates some of the traditional problems with PPPs (Deaton and Heston 2010, p. 12; Allen 2017). For a recent discussion on the merits of tithes as indicators of agricultural growth, see Álvarez-Nogal et al. (2016) and Reis (2016). We have made this change for the Porto, Coimbra and Lisbon hinterlands, but not Évora, which represents Alentejo and Algarve, where maize bread was not consumed.

${ }^{22}$ We not at present have sufficed good quality unskilled wages for these regions. 


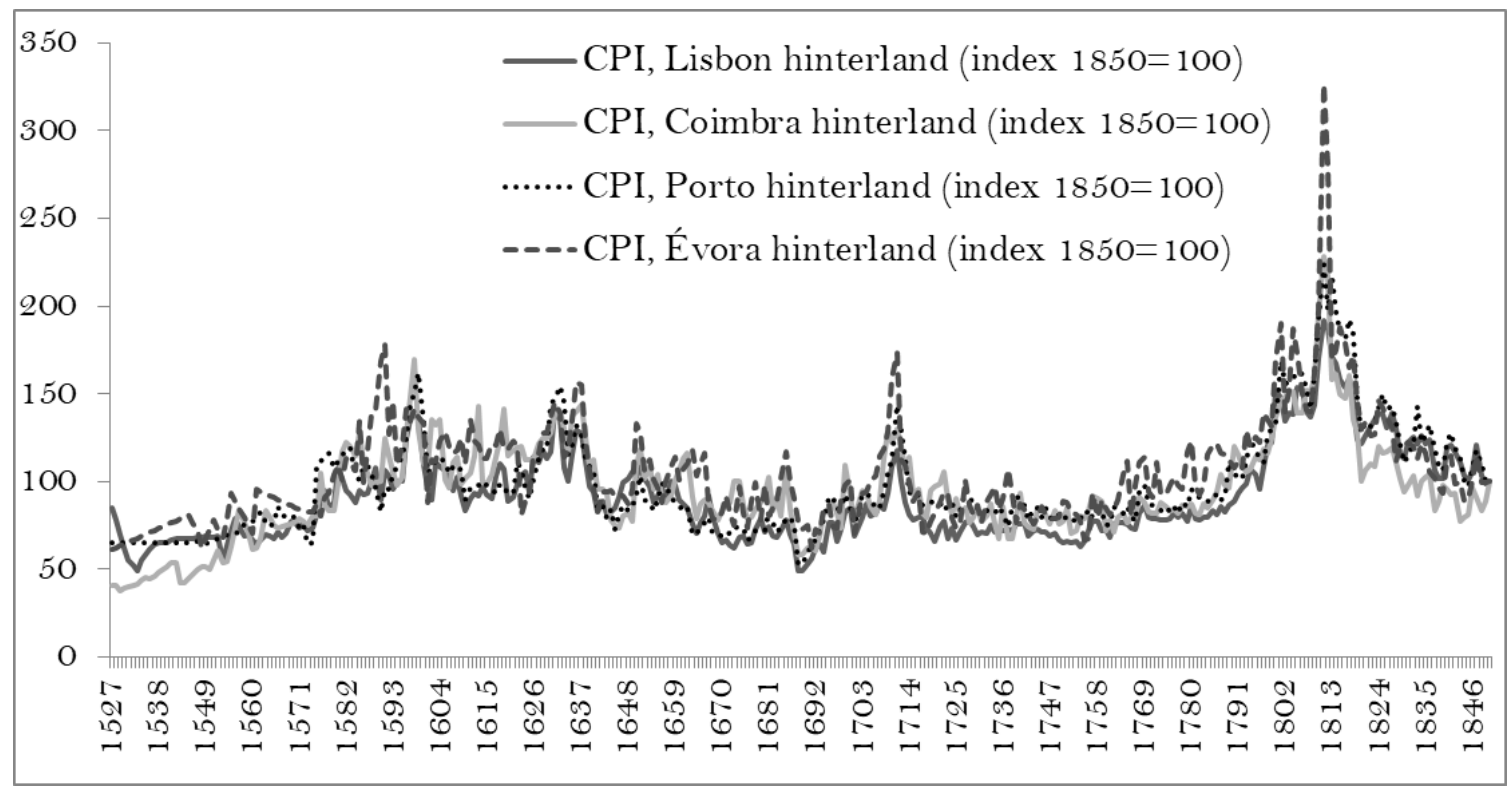

Figure 2. CPI for Portugal's four regions, 1527-1850. Sources: see text.

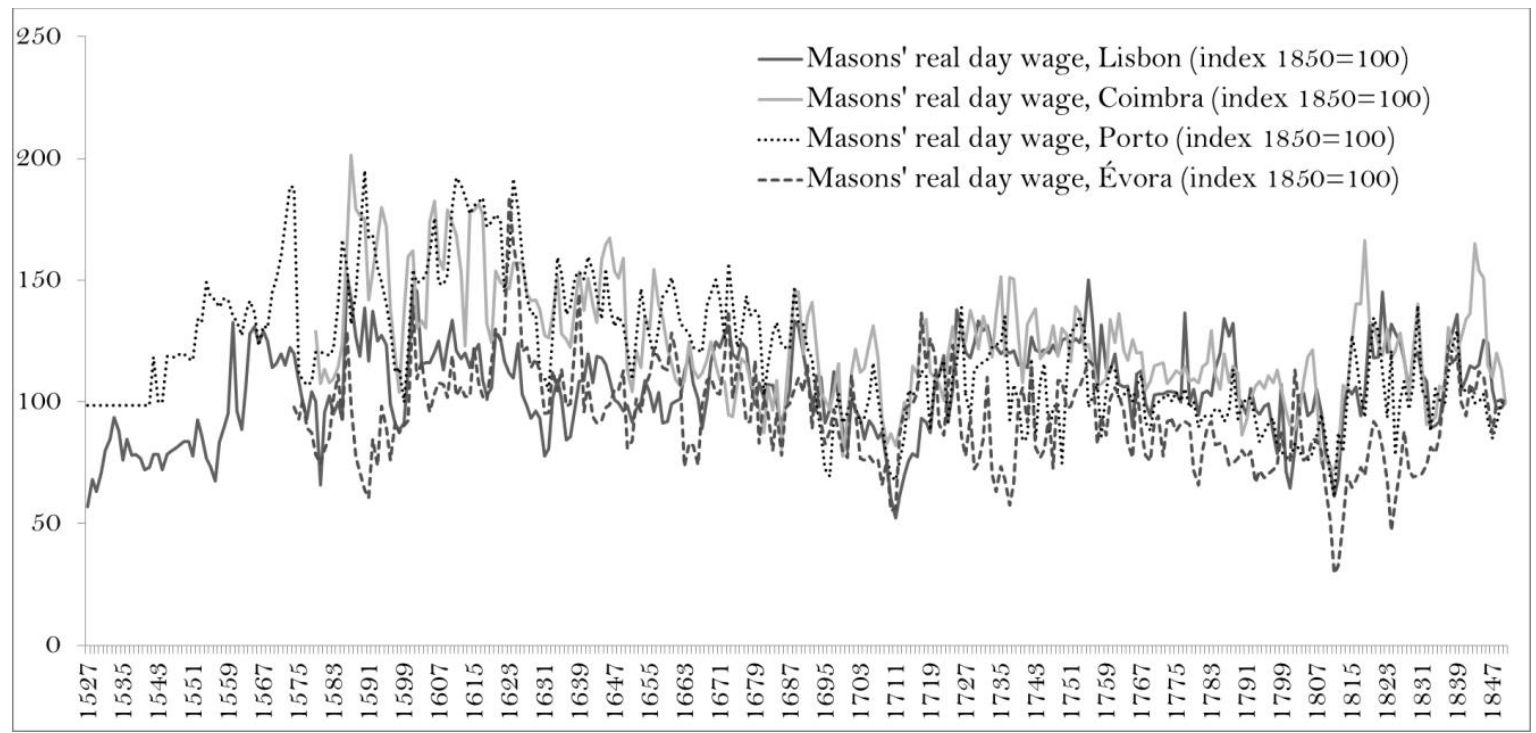

Figure 3. Skilled wages for Portugal's four regions, 1527-1850. Source: see text.

In Figure 4 we show our baseline national real day wage index. ${ }^{23}$ This is a weighted average of the wages of the four regions of the country, where the weights are given by their respective population shares. ${ }^{24}$ Each wage is in turn constructed by weighting the real incomes of unskilled, skilled, and mid-skilled workers according to their occupational shares at each given moment, by interpolating the values of Table 2 .

\footnotetext{
23 The separate evolution of the long-term real day wages for unskilled and skilled (masons) workers are shown in Figures A2 and A3 of the Appendix. The skilled premium is approximately constant over time.

${ }^{24}$ The source is Palma et al (2017). We only have annual population shares from 1574 onwards, so we assume they were constant at the 1574 level during 1527-1573. Furthermore, we only have reliable wage data for Porto's hinterland from 1541 onwards, for Coimbra's hinterland from 1579 onwards and for Évora's hinterland from 1574 onwards. For the periods from 1527 until these dates, we use our data for Lisbon's hinterland as a proxy.
} 


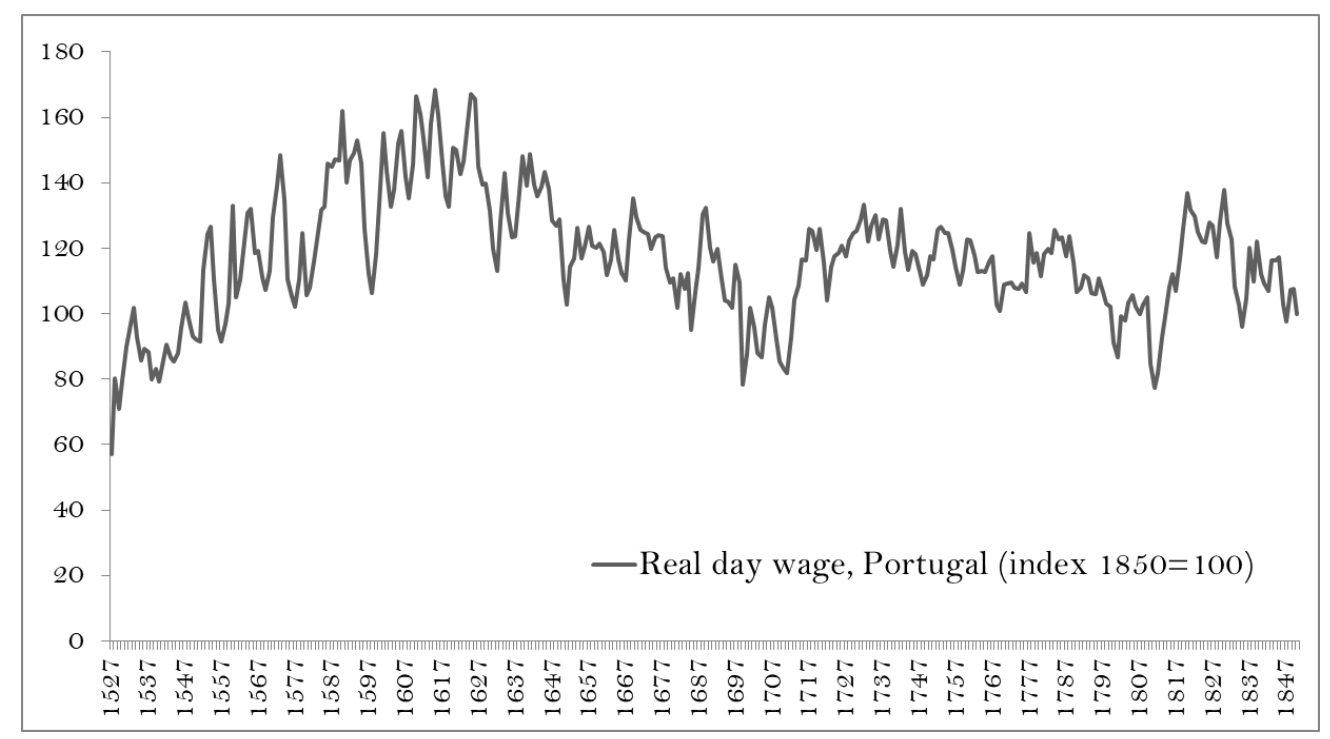

Figure 4. A national real day wage index for Portugal, 1527-1850 (index 1850=100). Sources: see text.

\subsection{Annual real earnings per worker}

In order to reflect change over time in the true number of days worked per year we now apply a supply-side adjustment to the preceding estimate. There is evidence that this indicator of labor intensity rose significantly over this period in Portugal, as it did elsewhere in Europe. ${ }^{25}$ In Portugal, this was a response to a more labor-intensive agricultural system required by the spread of highly-productive maize and wine (Ribeiro 1986), and to the economic opportunities offered by the empire (Costa et al. 2015). As a consequence, the growth of per capita income was bound to be higher than suggested by real wages calculated under the assumption of a fixed supply of labor per worker.

We now calculate the real annual earnings per worker from day wages, where the number of days worked varies both across time and by worker type. For any given year and region the weighted wage is given by

$$
\text { annual earnings per worker in region } j=\sum_{i=1}^{3} a_{i} w_{i j} l_{i}
$$

Where $\sum_{i} a=1$ are the weights corresponding to the occupational shares as given in Table $2, w_{i j}$ the day wage corresponding to each worker class in region $j$, and $l_{i}$ the number of days worked by each class, where $i=$ skilled, unskilled, and mid-skilled for that year.

Our procedure comprises two parts. The first one produces estimates of average yearly labor input per worker at the beginning and at the end of the period under observation. These benchmarks must be constructed independently from each other yet be consistent in their manner of construction. Once we have established the size of the differential between them, the second task is to split the additional long term labor effort into yearly variation over the peri-

\footnotetext{
${ }^{25}$ A nearby example is Spain, where between 1750 and 1850 the number of working days per year and per worker rose by 43 per cent. See Alvarez-Nogal and Prados de la Escosura (2013, p.7).
} 
od. Instead of interpolating linearly ${ }^{26}$ we use, as a plausible determinant of yearly increments, the share of maize in grain production based on the tithes received between the sixteenth and the nineteenth centuries by the bishopric of Viseu, a major grain producing region (Oliveira 1990, 2002). .7

For our baseline, we resort to a number of sources. Yearly skilled urban labor input is drawn from Brandão (1552), a definitive account of the city of Lisbon in the mid-fifteen hundreds. In general, the yearly work load revealed was 270 days, an unsurprising finding since it is equal to the days of the year minus Sundays and sanctified days. ${ }^{28}$ Similar data regarding unskilled workers in agriculture are unobtainable however and this obliges us to resort to an indirect approach. This involves constructing a supply-side estimate of the output of this sector, which we then divide by the current daily wage, to establish the total number of days of labor required for producing it. With this in hand, we infer the average yearly labor input per worker, by simply dividing this global labor effort by the number of workers engaged in agriculture.

To implement this method, we resort to two independent and creditable supply-side estimates of agricultural output. One is the sum of the gross valuations of the country's four main agricultural sectors circa 1515 - grain, wine, livestock products and olive oil - at current prices and converted into grams of silver, as proposed by Godinho (1968-72). We transform this aggregate as outlined above, using statistics of population and occupational shares from Tables 1 and 2, and also figures for silver prices and wages from the PWR data-base. We can hence recover the number of days worked: we obtain a result of 124 days per worker per year.

While informative, this method is not exempt from doubt, because Godinho does not make a direct reference the sources used. ${ }^{29} \mathrm{~A}$ second comparable case refers to 1530-1532 and adopts the same 4-sector model of agriculture, as well as the same labor force, price and wage data. It has a regional, rather than national dimension $-60,000$ acres in the northern hinterland of Coimbra (it is an area around Lamego shown in Figure 1) and a population of 36,000 but represents well the nation's agricultural productive structure (Reis 2016). The statistics for its agricultural volumes were calculated by Fernandes ([1532] 2012) using direct evidence from tithes. ${ }^{30}$ Our calculation of labor input per agricultural worker in this instance comes to 119 days per worker per year.

Given that these two methods produce similar outcomes, but the second is more reliable, we settle a choice of 120 days, which is the same as in Spain during the same period and for the same type of workers (Álvarez-Nogal and Prados de la Escosura 2013, p. 7). We complete

\footnotetext{
${ }^{26}$ Figure A4 in the Appendix shows that the quantitative results do not change very much if linear interpolation is used as an alternative.

${ }^{27}$ The first reliable observation corresponds to just over $20 \%$ in 1701 . We assume a level of $0.1 \%$ in 1600 , and interpolate linearly until 1701. The resulting values closely match a few partial observations available for the seventeenth century. For instance, under our procedure we assume about $13 \%$ for 1665 , while the true value was around $15 \%$ (Oliveira 1990).

${ }^{28}$ Note this is a more conservative choice (in the sense of generating less growth) than if we had chosen 250 days for skilled workers, as commonly done (e.g. Álvarez-Nogal and Prados de la Escosura 2013, Allen 2000).

${ }^{29}$ Detailed information on the source used by Godinho, the leading Portuguese economic historian of the post-war era, is not mentioned by him in keeping with the French historiographic practice of 60 years ago. But it is clear that the data arises in connection with a royal plan, around 1515 , to divert funds from the king's tithe income to pay new officials in the military orders. This would have required updated knowledge of the size of this revenue and therefore of agricultural income too. Regarding this reform, see Viterbo (1983). On the mechanics of tithe collection and distribution in the late fifteenth century, see Henriques (2015).

${ }^{30}$ Rui Fernandes, a rich merchant and tax contractor of the city of Lamego, was appointed to produce this survey of a circular area, with an 11 kilometer radius, centered on Lamego.
} 
this initial benchmark by assuming, for lack of additional evidence, that rural non-agricultural workers were employed an intermediate 195 days a year.

Obtaining similar indicators for our second benchmark is considerably easier since by the 1850 s economic statistics had become far more abundant, accessible and reliable. For skilled urban labor, we draw on government surveys covering the most significant regions from this point of view: Entre-Douro-e-Minho, Beira and Estremadura. They show that by this time the average for this indicator had ascended to 293 days a year, a small increment of 8.5 per cent relative to our starting point, and attributable to the decline in holy days since the 1750s (Coelho 1861; Silva 1861; Colaço 1862; Oliveira 1867). ${ }^{31}$ Meanwhile, the unskilled agricultural labor force had attained an annual input of 202 days per worker. This has been measured by replicating, with minor alterations, the methodology employed earlier for the baseline construction, with its same four sub-sectors, namely grain, wine, livestock and olive oil. ${ }^{32}$ It represents a rise of 67 per cent relative to the baseline. ${ }^{33}$ As above, we complete this benchmark by assuming again for rural non-agricultural workers an intermediate 247 days a year. ${ }^{34}$

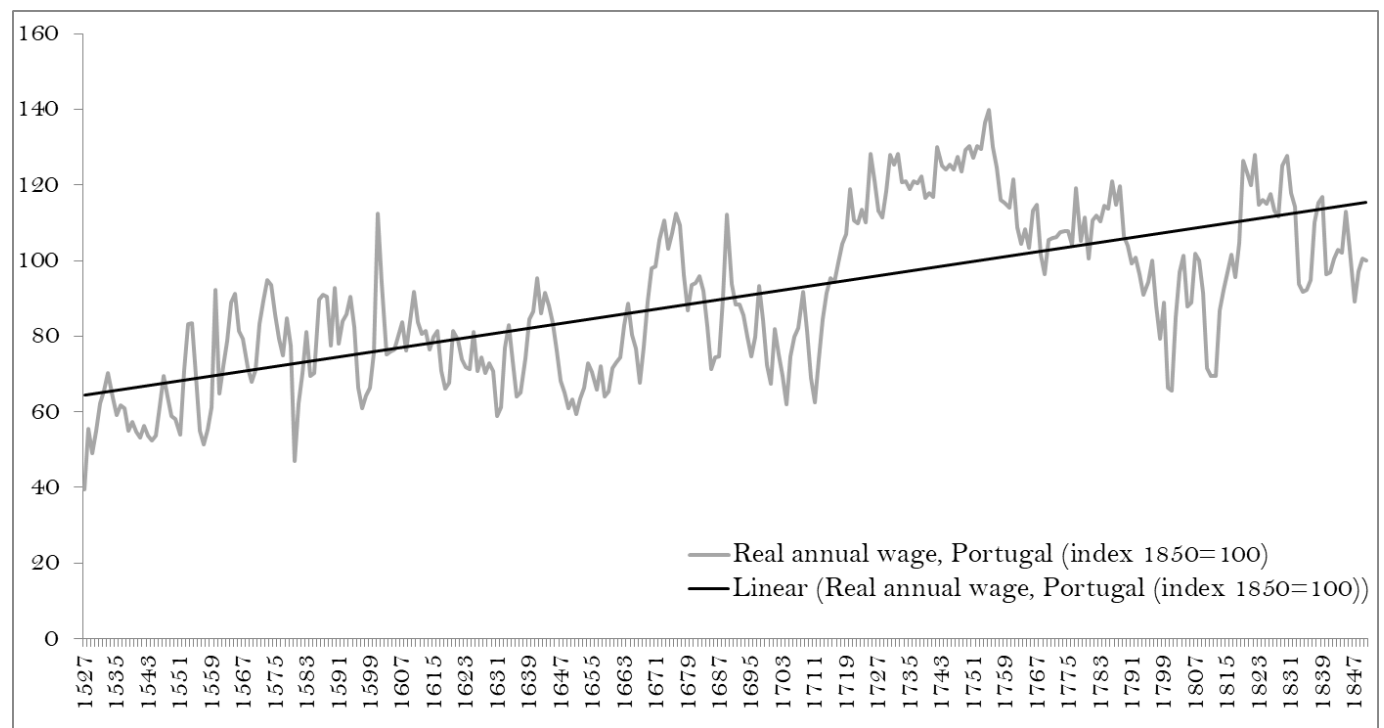

Figure 5. Real annual earnings per worker with varying labor supply. Sources: see text.

Using the resulting number of days worked for each worker type, we can hence calculate national annual wages. Figure 5 shows the result. There are three factors which explain why real annual earnings per worker grow, while the day wage of both skilled and unskilled workers are stagnant. First, structural change means that over time a higher proportion of

\footnotetext{
${ }^{31}$ With regards to the urban economy, the empire had the strongest impact from the mid-seventeenth century onwards (Costa et al. 2015). Our database also includes annual wages, which confirm this overall pattern of rising earnings from labor. Nonetheless, annual salaries generally correspond to white-collar professions of higher levels of human capital, like doctors and lawyers. We hence need to be cautious in comparing their evolution to that of the salaries of the occupations paid daily, because a divergence could be due, for instance, to higher returns to human capital. At the same time, the skill premium between white-collar and unskilled workers slightly declined during 1620-1764 (Reis 2016), which provides support for the idea that annual earnings did rise for all workers. ${ }^{32}$ The supply-side measure of agricultural output in 1850 is derived from a new generation of government statistics and is discussed in Reis (2000). At this time, new agricultural items such as potatoes, maize and rice were present and are included in in the category "grain".

${ }^{33}$ Rebello da Silva (1868), a distinguished contemporary agronomist, reckoned that 200 days was all that the agricultural year could offer laborers in terms of employment.

${ }^{34}$ By comparison, in Spain, the number of days worked increased 43\% between 1750 and 1850 (Álvarez-Nogal and Prados de la Escosura 2013, p. 7), and in Italy, they increased 80\% between the fifteenth century and 1850 (Federico and Malanima 2004).
} 
unskilled workers move to better paid mid-skilled and skilled wages. As Table 2 shows, the nonagricultural sector labor force increased from a trough of $30.5 \%$ in 1600 to a peak of $46.5 \%$ in the mid-eighteenth century. This effect is by itself small, and is already reflected in the evolution of our weighted day wage over time (Figure 4), as compared with the underlying trends of its inputs, the skilled and unskilled wages.

Second, not only is there an increasing share of skilled workers, but these workers are also occupied more days per year. Third, all workers also work more days as time went by. Over time (until 1750), not only did a higher share of workers get higher wages, but within worker types, they also worked more days in the year, a dynamic effect which compounded the higher day wage effects. The combination of these level effects over time leads to the temporary growth spurt visible in Figure 5.

Welfare ratios for Lisbon (calculated using the respectability basket and assuming a family of 3.15, as detailed in Allen 2001) illustrate how variable working days matter to explain the growth of annual consumption as opposed to day wages. (We show these for Lisbon rather than Portugal in order to be more directly comparable to Allen's other cities.) Figure 6 show welfare ratios for Lisbon for both skilled and unskilled workers under different assumptions about working time: either fixed (but variable by class), or, variable by class but increasing over time. In the absence of proper PPPs for the past, they also illustrate the fact that Lisbon's workers were faring relatively well by international standards; in the mid-eighteenth century, only Antwerp, Amsterdam, and London (from Allen 2000, p. 428) had higher consumption patterns than Lisbon.

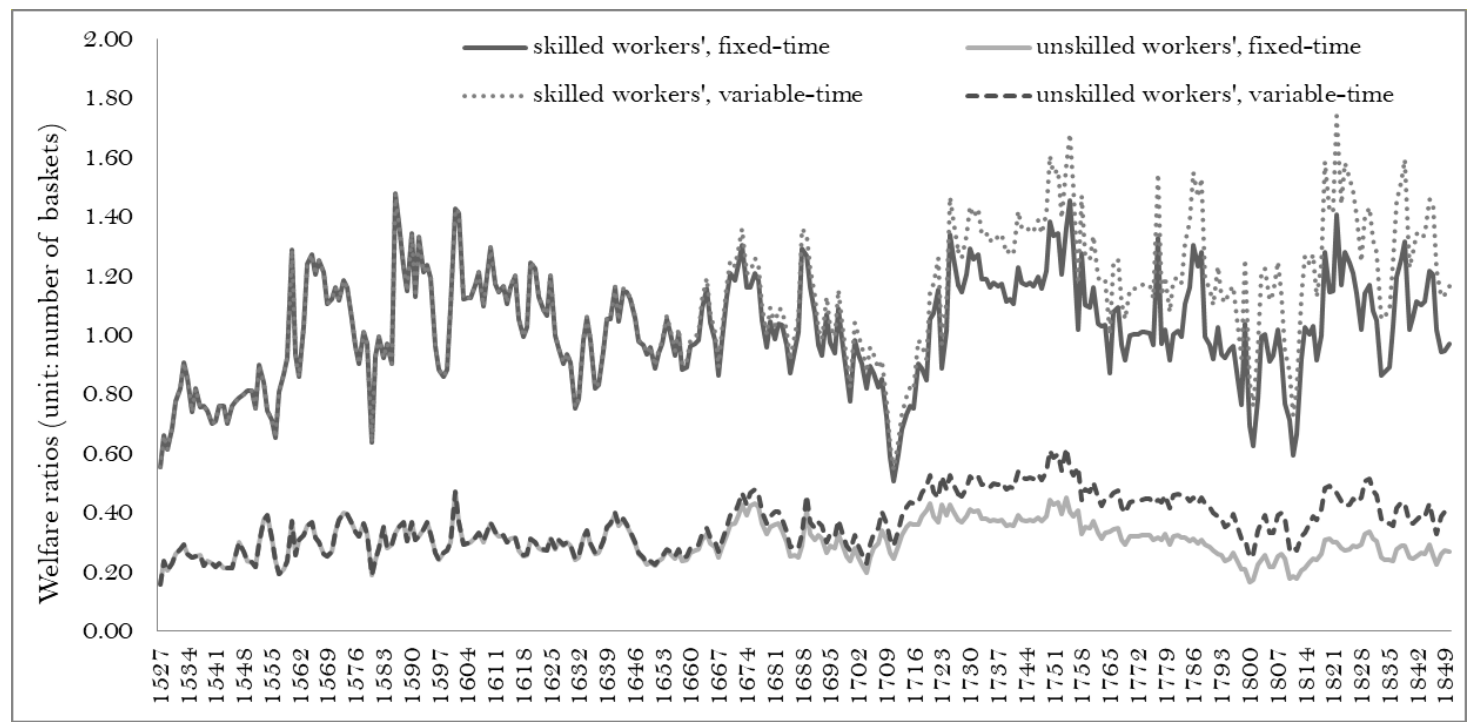

Figure 6. Welfare ratios for Lisbon (respectability baskets). Sources: see text.

\subsection{Agricultural GDP}

Portugal's agricultural product over this period has been estimated by Reis (2016), partly relying on results from an earlier version of the present paper. Here we provide a short summary of the procedure, which we further improve upon. The first part of the exercise uses a demand-for-food function to obtain gross agricultural output, taken to be equal to food con- 
sumption (Wrigley 1985, Allen 2001) given the practical equivalence between them in the Portuguese case. ${ }^{35}$ For any given year, the agricultural product $\left(Q_{a}\right)$ is given by the expression,

$$
Q_{a}=P^{\alpha} I^{\beta} M^{\chi} N
$$

in which $P$ is the real price of agricultural products, $I$ is real income per capita, $M$ is the real price of other consumer goods and $N$ is total population. The coefficients $\alpha, \beta$ and $\chi$ are, respectively, the own price, income and cross elasticities of demand. This function takes into account the impact on food consumption of fluctuations in real income, food prices and nonfood prices, as well as their respective elasticities.

A fairly wide range of choices exists with regard to the selection of demand and income elasticities. In the absence of anything better, the literature has resorted to emulating the present day elasticities of less developed economies with traits presumed similar to those of early modern economies. The possibilities go from -0.4 to -0.7 , for own-price elasticity, and from 0.3 to 0.6 for income elasticity. We have found the arguments advanced by Álvarez-Nogal and Prados de la Escosura (2013) convincing and have therefore opted here for the set they propose in which $\alpha=-0.4, \beta=0.3$ and $\chi=0.1$.

The principal difficulty with this model is how to quantify the real income variable. The best solution to date is that proposed by Álvarez-Nogal and Prados de la Escosura (2013, p. 9), who employ a weighted index of wages (0.75) and land rents (0.25). ${ }^{36}$ Including land rents slightly increases the volatility of the income series, but does not change the result significantly. We hence build an overall income index which we then deflate using our CPI. Figure 7 shows the result. ${ }^{37}$

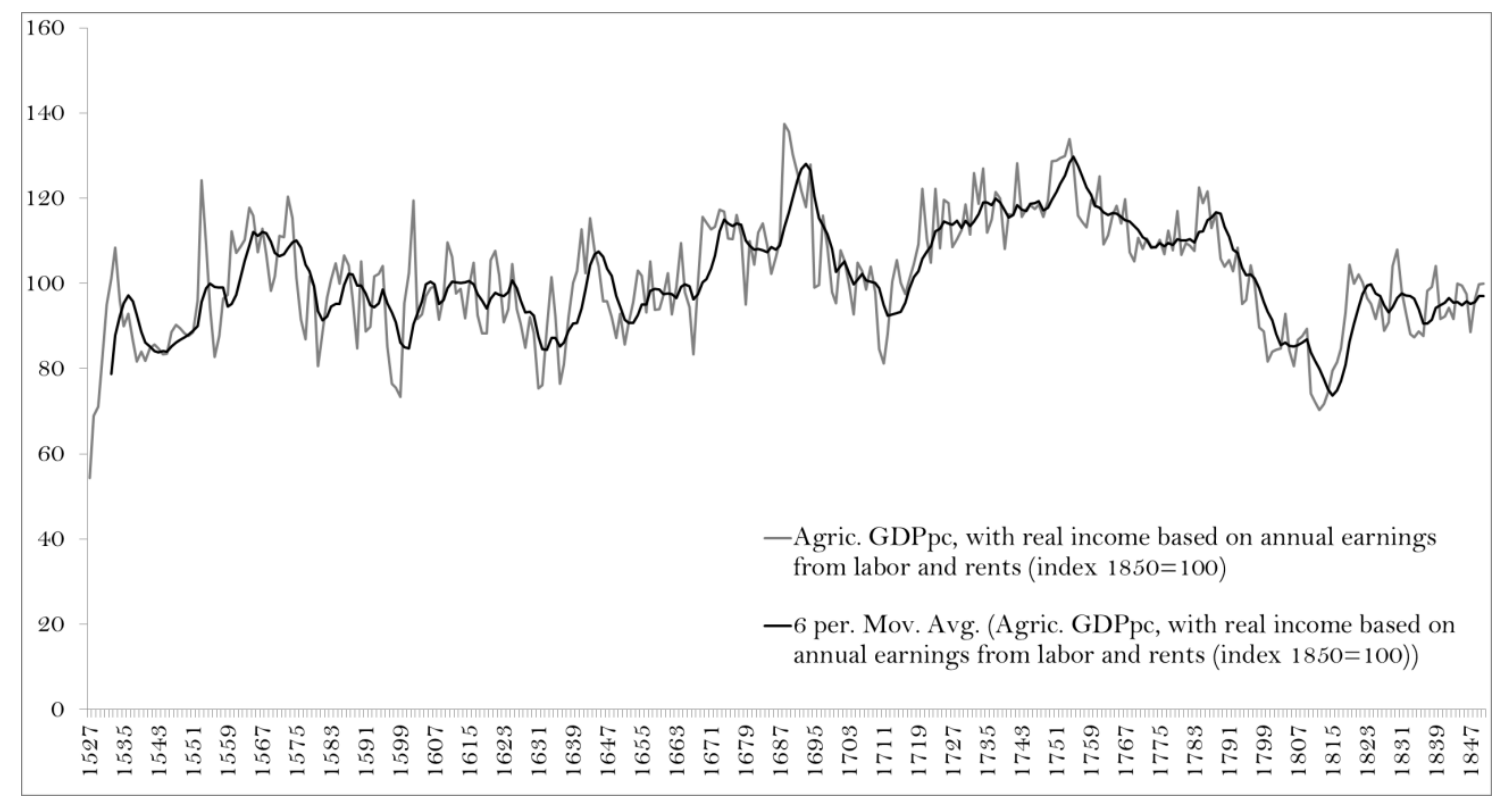

Figure 7. Agricultural real GDP per capita. Sources: see text.

\footnotetext{
35 The online Appendix (Table A2) shows the very small size of the differential between food imports and exports and compares it to agricultural output. See Costa and Reis (2017).

${ }^{36}$ The result is very similar to summing yearly the actual current-price wages and rents as in Álvarez-Nogal and Prados de la Escosura (2013).

${ }^{37}$ Figure A6 in the appendix compares this result with that using the day wage as the only source of income.
} 


\subsection{Real per capita GDP}

The second major step in estimating GDP is the quantification of the non-agricultural part of the economy. Both Malanima (2011) and Álvarez-Nogal and Prados de la Escosura (2013) have postulated a significantly stable relation between the urban share of the population and the size of the secondary and tertiary sectors together. The former has extrapolated this link all the way back to 1300 using the coefficients of a linear regression covering the years 1861-1936. In it, non-agricultural output was the dependent variable and urbanization served as the covariate. The latter used change over time in the country's "adjusted" urbanization rate to proxy for the variation in the size of the nonagricultural economy, and then backed up current-price values for both the agricultural and nonagricultural sectors by using, respectively, the agricultural CPI, and an index which consists of an average of the industrial CPI, the global CPI, and the nominal wage (Álvarez-Nogal and Prados de la Escosura 2013, p. 14-16).

Both approaches have disadvantages, the principal one being that focusing on urban production alone entails ignoring the contribution of proto-industry to non-agricultural production. Another is that they overlook the more than likely rise in productive efficiency which arose in parts of the economy during the preindustrial era. To surmount them, we resort to the procedure proposed by Pfister et al (2012) for Germany by assuming a constant ratio between the share of agriculture in total output and its share of employment. In other words, we maintain that the inter-sectoral productivity gap $(p)$ between agriculture and total output is timeinvariant over the period considered. The expression for GDP at any given year $t$ is then,

$$
G D P_{t}=Q_{a, t} /\left(p \times \frac{L_{a, t}}{L_{t}}\right)
$$

in which $Q_{a, t}$ is agricultural output and $L_{a, t}$ and $L_{t}$ are agricultural and total labor respectively, all of them at time $t$, and $p$ is the constant productivity gap. Since we possess estimates of agricultural output (Reis 2016) and of major sectoral shares (discussed next), all that is needed to derive GDP is to determine this gap at a point in time for which this is possible and then extrapolate the desired result back as far as needed. We resort to an estimate for Portugal of $p$ from the mid-nineteenth century (1850) $)^{38}$ which is of a credible order of magnitude. It is lower than those for Italy (Malanima 2011) and Germany (Pfister 2011) and similar to the value derived for Spain (Álvarez-Nogal and Prados de la Escosura 2007). ${ }^{39}$ The expression for obtaining the value of $p$ is,

$$
p_{1850}=\frac{Q_{a, 1850} / Q_{n a, 1850}}{L_{a, 1850} / L_{n a, 1850}}
$$

where $Q_{a, 1850}$ is agricultural output, $Q_{n a, 1850}$ is non-agricultural output and $L_{a, 1850}$ and $L_{n a, 1850}$ are, respectively, the total labor of these two sectors, at the year 1850 . The value we adopt for Portugal is 0.7, the unweighted mean of those obtained from data found, respectively, in Lains (2003) and Reis (2000). The result using this constant inter-productivity gap (IPG) method is our baseline result for real per capita GDP, as shown in Figure 8, and in the continuous black line of Figure 9.

\footnotetext{
${ }^{38}$ Notice that this year is prior to the outset of major structural changes in Portugal; see Lains (2003).

${ }^{39}$ For Spain, the value is 0.66 , and for Italy and Germany it is 0.81 , plausibly suggesting a higher level of economic development in the last two countries.
} 


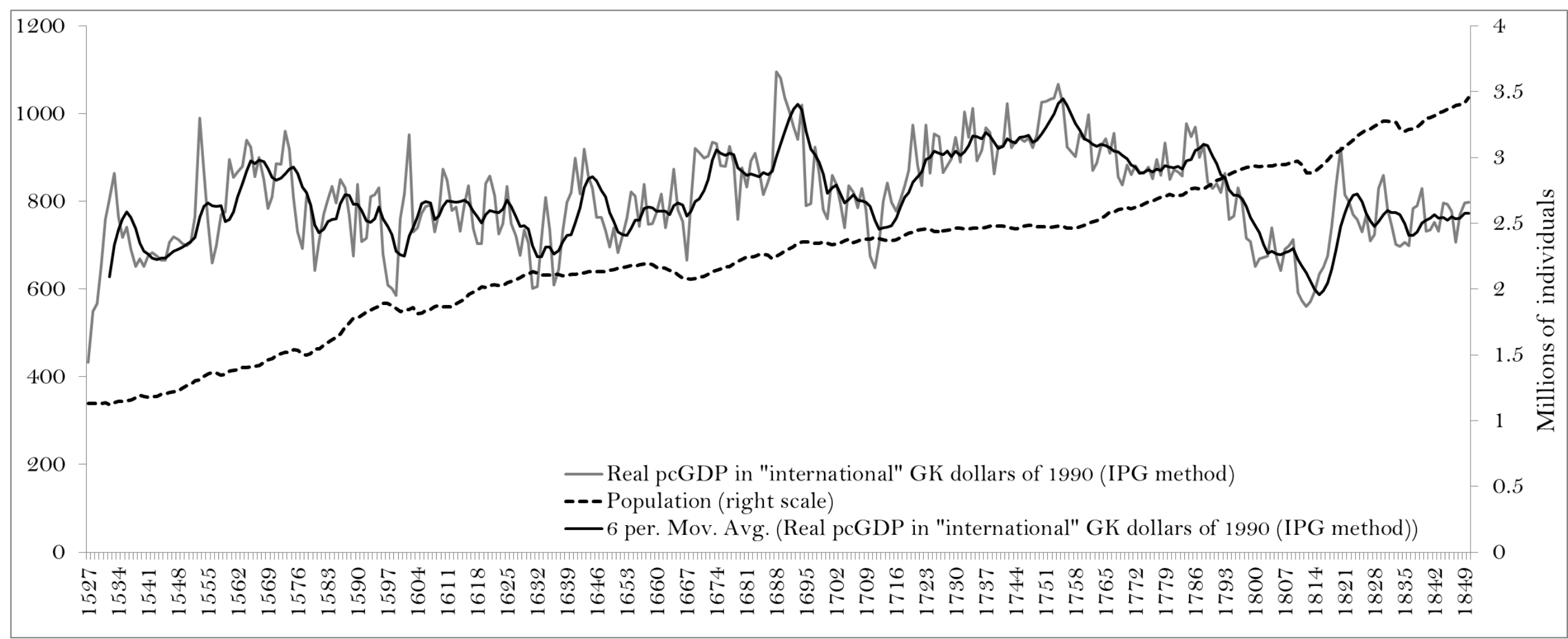

Figure 8. Portugal's GDP per capita (in "international” GK dollars of 1990, left scale) and population (right scale), 1527-1850. Sources: for GDP see text, for population: see text and Palma et al. (2017). 
There are two alternatives which can be used to estimate a time-varying inter-sectorial productivity gap. The first is that of Malanima (2011), which relies on a regression of the size of the nonagricultural product on a constant and, as a covariate, the urbanization ratio. ${ }^{40} \mathrm{We}$ show the result with this method in Figure 9. The second is the method of Álvarez-Nogal and Prados de la Escosura (2013, pp. 14-16), which uses change over time in Portugal's urbanization rate to proxy for the variation in the size of the nonagricultural economy, and then backs up current-price values for both the agricultural and nonagricultural sectors. This is done by using, respectively, the agricultural CPI, and an index which consists of an average of the industrial CPI, the global CPI, and the nominal wage. ${ }^{41}$ This method is also shown in the Figure 9. As the figure suggests, the different methods lead to similar results.

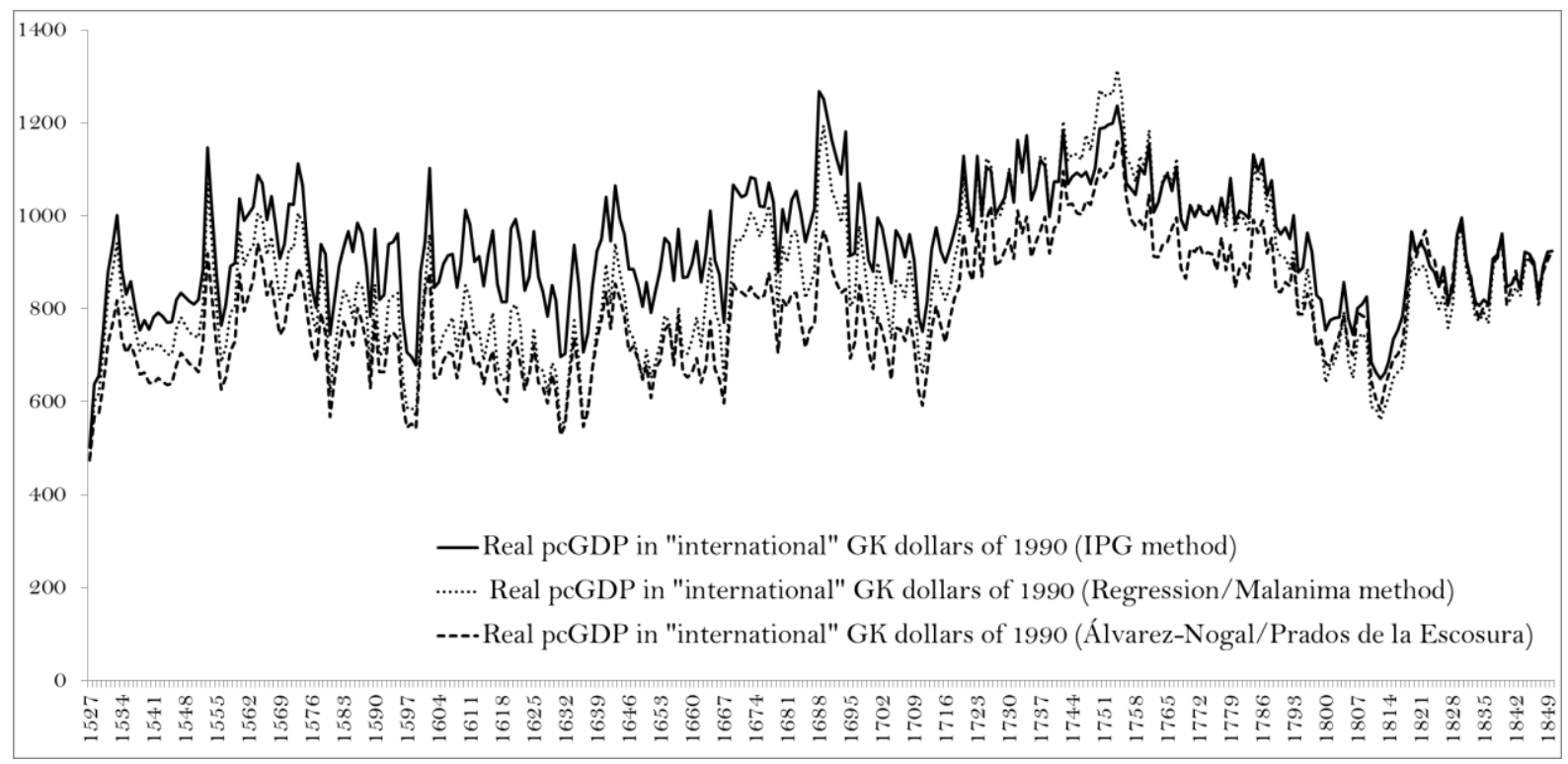

Figure 9. Per capita real GDP using alternative methods to calculate the inter-sectorial productivity gap. Sources: see text.

\section{Discussion and international comparisons}

\subsection{A stagnant economy?}

The notion of persistent Early Modern stagnation is related to that of the structural inability of these economies to generate technical and organizational change on an appreciable scale. In order that some growth should happen at the intensive margin, three conditions needed to be met. One was that innovation would occur and influence sizable sectors of the economy. Another is that it would have to translate into palpable productivity gains. The third is that this impetus would have to be sustained over a relevant time span. Recent research on preindustrial Britain and Holland demonstrates that they possessed these attributes and thus contradict the view of Malthusian historians. The relative dynamism of Portugal's performance over long periods of time suggests that it may have been yet another country which did not fit the condition of economic torpor depicted by the standard literature. Nonetheless, from a very

\footnotetext{
${ }^{40}$ Our regression covers the 1848-1923 period, with Leite (2005) for the urbanization ratio, and the size of the nonagricultural sector inferred from the current-price value of services and industry over total GDP, taken from Lains (2003).

${ }^{41}$ For the current-price value of agriculture in 1850, we used Reis (2000).
} 
long perspective it stands true that Portugal's per capita real income was no higher in 1850 than it had been in the early 1530 s.

As Figure 8 documents, the sixteenth century did not witness any overall progress. But since the early 1630 s a completely different picture is visible. Three forces were mainly responsible for changing this country's economy and instilling it with a clear impulse to grow. One was the spread from around sixteen hundred of a new irrigated, highly productive crop - Indian or American maize - which displaced traditional foodstuffs and established entirely new production and consumption patterns (Ribeiro 1986). Another was the development, from the late-seventeenth century, of a highly commercialized and competitive Port wine sector which established a remarkable export vocation focused on the flourishing British market (Martins 1990). The third was the establishment throughout the whole of the early modern period of an overseas empire, which linked the mother country, through a complex web of sea lanes and mercantilist ties, to a multiplicity of profitable settlements and trading posts (Costa et al. 2015). It is remarkable that the timing of the c. 1710-1750 boom coincides with that of the entry of Brazilian gold (Costa et al 2013). All of these were gradual developments which invoked a capacity for technical and organizational change, as well as for major investment in human, physical and financial capital. All of them had significant long-run macroeconomic implications. ${ }^{42}$

\subsection{Comparative per capita GDP levels}

Portugal's economy is held to have been comparatively backward during the early modern period (Allen 2005, van Zanden 2009). By contrast, we have shown that the Portuguese economy experienced 120 years of per capita growth between 1630 and 1754: $0.54 \%$ a year. ${ }^{43}$ Portugal's growth rate hence compares favorably with that of the Netherlands, of $0.41 \%$ per year during 1500-1650, and that for England/Britain, of $0.30 \%$ for $1600-1750$, their respective golden ages of early modern growth.

We now shift the discussion from volume-based measures to a comparison of income levels. Table 4 shows the results using the well-known Maddison method. ${ }^{44}$ Portugal's favorable circumstances by the mid-eighteenth century, which were largely the result of remarkable growth in the previous half century - but also dated back to the early seventeen hundreds were not to last. In the very long run, the economy conformed to the predictions of the Malthusian model. Despite variation in response to shocks, income converted back to what could be interpreted as a long-term "subsistence" level. Nonetheless, while the forces of convergence to such a steady state did include endogenous fertility and mortality responses in the spirit of Malthus, it is equally possible that negative effects of a political economy or institutional nature were also present.

\footnotetext{
${ }^{42}$ For an up-to-date overview of this period's economic history, see Costa et al (2016).

${ }^{43}$ This annualized growth rate was calculated using the familiar compound growth formula.

${ }^{44}$ Maddison gives 923 GK international 1990 dollars for both 1820 and 1850 . Our data show these two are inconsistent. We pick the least remote value, 1850, as the preferred one.
} 


\begin{tabular}{|c|c|c|c|c|c|c|c|c|c|}
\hline & England/GB & Holland & Germany & France & $\begin{array}{c}\text { North } \\
\text { and } \\
\text { Central } \\
\text { Italy } \\
\end{array}$ & Spain & Sweden & $\begin{array}{c}\text { Portugal } \\
\text { (Maddison } \\
\text { 2003) }\end{array}$ & $\begin{array}{c}\text { Portugal } \\
\text { (this study) }\end{array}$ \\
\hline 1500 & 1068 & 1454 & 1146 & 935 & 1553 & 846 & - & 606 & - \\
\hline 1550 & 1058 & 1798 & - & - & - & - & $\begin{array}{c}995 \\
(\mathrm{y} .1560) \\
\end{array}$ & - & 809 \\
\hline 1600 & 1082 & 2662 & 806 & 901 & 1363 & 892 & 761 & 740 & 880 \\
\hline 1650 & 925 & 2691 & 948 & - & 1398 & 687 & 966 & - & 856 \\
\hline 1700 & 1513 & 2105 & 939 & 992 & 1476 & 814 & 1340 & 819 & 880 \\
\hline 1750 & 1695 & 2355 & 1050 & - & 1533 & 783 & 973 & - & 1188 \\
\hline 1800 & 2097 & 2609 & 986 & 1045 & 1363 & 916 & 857 & $\begin{array}{c}923 \\
\text { (y. 1820) } \\
\end{array}$ & 754 \\
\hline 1850 & 2330 & 2355 & 1428 & 1597 & 1481 & 1079 & 1076 & 923 & 923 \\
\hline
\end{tabular}

Table 4. Output per capita in Europe in "international" GK dollars of 1990. Data for Portugal shown extrapolating backwards from the 1850 benchmark in Maddison (2003, p. 66). For France until 1800, levels are taken from Ridolfi (2016, p. 197). For the others, growth rates are taken for the following sources: for England/GB, Broadberry et al (2015); for Holland, van Zanden and van Leuween (2012); for Germany, Pfister (2011); for France in 1850, Álvarez-Nogal and Prados de la Escosura (2013, p. 23); for North and Central Italy, Malanima (2011); for Spain, Allvarez-Nogal and Prados de la Escosura (2013); for Sweden, Schön and Krantz (2012).

\section{Conclusion}

The effort to understand the historical origins of modern economic growth necessarily involves paying attention to the European periphery. Understanding what went wrong in the periphery is a crucial part of the effort to make sense of what went right in Northwestern Europe. Knowing how prices, rents, income and population evolved in the countries that lagged behind is a critical piece of the puzzle, as it provides a source of variation in the data which allows us to compare them with the modernizing economies. The behavior of such major macroeconomic variables during the early modern period was already well known for England, Holland, Germany, Sweden, Italy, and Spain. ${ }^{45}$ In this study we have considered the case of Portugal, which has so far been absent from the literature.

How do the statements by Thomas and McCloskey (1981) and by Bairoch (1976) in the first paragraph of our paper stand up in comparison with the evidence we have gathered?

1. During much of the early modern period Portugal was comparatively prosperous. While a loss of dynamism is already noticeable from the second half of the eighteenth century, as late as 1750 income levels in Portugal were high by Western European standard though clearly behind those in Britain, Hollan, and North/Central Italy.

2. At least between c. 1630-1750, Portugal was not Malthusian, in the sense that per capita income did not have a tendency to converge towards a stagnation steady-state, despite the growth in population. Much growth was of an extensive na-

\footnotetext{
45 See, for England, Allen (2001), and Broadberry et al (2015); for Holland, van Zanden and van Leeuwen (2012); for Germany, Pfister (2011), and Pfister et al (2012); for Sweden, Edvinsson (2013a, b) and Schön and Krantz (2012); for Italy, Malanima (2011, 2013); and for Spain, Álvarez-Nogal and Prados de la Escosura (2007, 2013).
} 
ture, but Malthusian forces were not sufficient to cancel Smithian intensive growth opportunities.

3. Portugal provides support for an early modern European "little divergence". The timing of convergence or divergence depends on the country of reference, but Portugal's income levels were below those of the most advanced countries for all of the early modern period, as shown in our Table 4. Nonetheless, there were periods of convergence such as the first half of the seventeenth or eighteenth centuries. Compared with England/GB, an unmistakable divergence in the income differentials happened in the course of the early modern period, but it dates from no earlier than the second half of the eighteenth century. ${ }^{46}$

4. After the mid-eighteenth century Portugal entered a period of persistent decline which had as proximate causes the increase in population combined with the exhaustion of the previously available engines of economic growth without their substitution by new sources. Whether there was also an institutional element in this decline and how it may be related to the previous resource boom remains unclear at the moment. What is certain is that the growth which had taken place until then was accompanied by limited structural change.

We have offered an account of the main proximate factors of the growth and decline of Portugal's economy from the early sixteenth to the mid-nineteenth century. This has enabled us to add Portugal to the pool of existing evidence on GDP, as well as factor and commodity prices and allows us to round off the usual picture for early modern Europe with the inclusion of a non-core economy in this context. We have concluded that although Portugal enjoyed comparatively high incomes well into the early modern period, its structural modernization was comparatively slow. As the engines of growth ran out of steam after c.1750, a reversal took place which, within a century, would leave Portugal as one of the poorest countries in Europe.

\section{References}

Allen, Robert C. (2000). Economic structure and agricultural productivity in Europe, 1300-1800. European Review of Economic History 4: 1-25.

Allen, Robert C. (2001). The Great Divergence in European Wages and Prices from the Middle Ages to the First World War. Explorations in Economic History, 38, 41 1-447.

Allen, Robert C. (2003). Progress and Poverty in Early Modern Europe. Economic History Review 3, 403-443.

Allen, Robert C. (2005). Real Wages in Europe and Asia: A First Look at the Longterm Patterns. In: Living Standards in the Past. New Perspectives on Well-Being in Asia and Europe, eds. Allen, Robert C., Bengtsson, Tommy and Martin Dribe. Oxford: Oxford University Press.

Allen, Robert C. (2017). Absolute Poverty: When Necessity Displaces Desire. American Economic Review 107, 3690-3721.

Álvarez-Nogal, Carlos and Leandro Prados de la Escosura (2007). The decline of Spain (1500-1850): Conjectural estimates. European Review of Economic History 11, 319-366.

${ }^{46}$ For a similar finding but using real wages, see Malanima (2013). 
Álvarez-Nogal, Carlos and Leandro Prados de la Escosura (2013). The rise and fall of Spain (1270-1850). The Economic History Review 66 (1): 1-37.

Álvarez-Nogal, Carlos, Prados de la Escosura, Leandro and Carlos Santiago-Caballero (2016). Spanish agriculture in the little divergence. European Review of Economic History 4, 452477.

Bairoch, P. (1976). Europe's Gross National Product: 1800-1975. Journal of European Economic History 5, 273-340.

Bairoch, P., Batou, J. and P. Chèvre (1988). La Population des Villes Européennes, 8001850. Geneva: Librairie Droz. Horizonte.

Brandão, João (1990 [1552]). Grandeza e Abastança de Lisboa em 1552. Lisboa: Livros

Broadberry, S., Campbell, B., Klein, A., Overton, M. and B. van Leeuwen (2015). British Economic Growth 1270-1870. Cambridge: Cambridge University Press.

Costa, L., Lains, P. and S. Miranda (2016). An Economic History of Portugal, 1143-2010. Cambridge: Cambridge University Press.

Costa, Leonor, Palma, Nuno and Jaime Reis (2015). The great escape? The contribution of the Empire to Portugal's economic growth, 1500-1800. European Review of Economic History $19,1-22$.

Costa, Leonor and Jaime Reis (2016). The chronic food deficit of early modern Portugal: Curse or myth? Working Papers of GHES, No 2016/58.

Costa, L., Rocha, M. and R. Sousa (2013). O Ouro do Brasil. Lisboa: Imprensa NacionalCasa da Moeda.

Costa Leite, Joaquim (2005). População e crescimento económico. In: Pedro Lains and A. Ferreira da Silva (eds.), História Económica de Portugal, 1700-2000 (vol. 2). Lisboa: ICS

Clark, Gregory (2007). A Farewell to Alms. A Brief Economic History of the World. Princeton University Press. Nacional.

Coelho, Eusébio (1861). Estatistica do Districto de Vianna do Castello. Lisboa: Imprensa

Colaço, Gregório (1862). Informação para a estatística industrial dos disritos de Leiria e Funchal. Lisboa: Imprensa Nacional.

Costa, Leonor and Jaime Reis (2017). The chronic food deficit of early modern Portugal: Curse or myth? Análise Social LII, 416-429.

Deaton, A. and A. Heston (2010). Understanding PPPs and PPP-based National Accounts. American Economic Journal: Macroeconomics 2, 1-35. 
Edvinsson, Rodney (2013a). New annual estimates of Swedish GDP, 1800-2010, Economic History Review, 66, 1101-1126.

Edvinsson, Rodney (2013b). Swedish GDP 1620-1800: stagnation or growth?, Cliometrica, 7, 37-60.

Fernandes, Rui (2012 [1552]). Descrição do terreno ao redor de Lamego duas léguas, 1531-1532. Amândio Morais Barros (ed.). Casal de Cambra: Caleidoscópio.

Fonseca, Jorge (1986). Uma Vila Alentejana no Antigo Regime - Aspectos sócioeconómicos de Montemor-o-Novo nos séculos XVII e XVIII. Almansor-Revista de Cultura 4, 119-207.

Fonseca, Helder and Jaime Reis (2011). The limits of agricultural growth in a fragile eco-system: Total factor productivity in Alentejo, 1750-1850. In: Olsson, M. and P. Svensson (eds.) Growth and Stagnation in European Historical Agriculture. Turnhout: Brepols, 37-66.

Fouquet, R., and Broadberry, S. (2015). Seven centuries of European economic growth and decline. Journal of Economic Perspectives, 29 (4).

Godinho, Vitorino Magalhães (1968-1972). Ensaios. Lisboa: Sá da Costa, 4 vols.

Henriques, Antonio C. (2015). Plenty of land, land of plenty: the agrarian output of Portugal (1311-20). European Review of Economic History 19, 149-170.

Humphries, J., and Weisdorf, J. L. (2017). Unreal Wages? Real Income and Economic Growth in England, 1260-1850. CEPR discussion paper.

Lains, Pedro (2003). Os Progressos do Atraso: Uma Nova História Económica de Portugal, 1842-1992. Lisboa: Imprensa de Ciências Sociais.

Leite, Joaquim (2005). População e crescimento económico. In: Pedro Lains and A. Ferreira da Silva (eds.), História Económica de Portugal, 1700-2000 (vol. 2). Lisboa: ICS.

Lopes, José S. (2004). A Economia Portuguesa no Século XX. Lisboa: Imprensa de Ciências Sociais.

Maddison, Angus (2003). The World Economy, Volume 2: Historical Statistics. OECD.

Maddison, Angus (2010). Statistics on world population, GDP and per capita GDP, 12008 AD. Groningen Growth and Development Centre. Accessed 9 of September 2016 from: http://www.ggdc.net/maddison/oriindex.htm

Malanima, Paolo (2011). The long decline of a leading economy: GDP in central and northern Italy, 1300-1913. European Review of Economic History 15, 169-2 19.

Malanima, Paolo (2013). When did England overtake Italy? Medieval and early modern divergence in prices and wages. European Review of Economic History 1, 45-70. 
Marques, A. H. de Oliveira (1980). Estratificação económico-social de uma vila portuguesa na Idade Média. In: Marques, A. H. de Oliveira (Ed.). Ensaios de História Medieval Portuguesa. Lisboa: Vega, 121-133. Sociais.

Martins, Conceição (1990). Memória do Vinho do Porto. Lisboa: Instituto de Ciências

Monteiro, Nuno (2005). A ocupação da terra. In Lains, Pedro and Álvaro Silva (eds). História Económica de Portugal (Lisboa: ICS), vol. I, 67-92.

Oliveira. Francisco (1867). Informação para a estatística industrial publicadas pela Repartição de Pesos e Medidas do distrito de Aveiro. Lisboa: Imprensa Nacional.

Oliveira, João (1990). A Produção Agrícola de Viseu entre 1550 e 1700 . Viseu: Câmara Municipal de Viseu.

Oliveira, João (2002). A Beira Alta de 1700 a 1840. Gentes e Subsistências. Viseu: Palimage.

Palma, Nuno, Jaime Reis and M. Zhang (2017). Reconstruction of regional and national population using intermittent census-type data: the case of Portugal, 1527-1864. MaddisonProject Working Paper WP-8

Pamuk, Sevket and Ozmucur, Suleiman(2002), Real wages and standards of living in the Ottoman empire, 1489-1914. Journal of Economic History, 62, 293-32 1

Pfister, Ulrich (2011). Economic growth in Germany, 1500-1850. Unpublished manuscript. Presented at the "Quantifying long run economic development" conference, University of Warwick in Venice.

Pfister, Ulrich, Riedel, Jana and Martin Uebele (2012). Real wages and the origins of modern economic growth in Germany, $16^{\text {th }}$ to $19^{\text {th }}$ centuries. EHES Working Papers in Economic History, $\mathrm{N}^{\mathrm{o}} 17$.

Rebello da Silva, Luís (1868). Compêndio de Economia Rural. Lisboa: Imprensa Nacional.

Reis, Jaime (2000). How poor was the European periphery before 1850? The Mediterranean vs. Scandinavia. In: The Mediterranean response to Globalization before 1950, S. Pamuk and J. Williamson (eds.). London: Routledge, 17-44.

Reis, Jaime (2005). O trabalho. In Lains, Pedro and Silva, Álvaro da (eds.) História de Portugal. Lisboa: ICS, vol. 2, 119-151.

Reis, Jaime (2016). Gross agricultural output: a quantitative, unified perspective, 15001850. In: An Agrarian History of Portugal, 1000-2000. Economic development on the European frontier, eds, Dulce Freire and Pedro Lains. Leiden: Brill, pp. 166-196. 297-319.

Reis, J. (2017). Deviant behaviour? Inequality in Portugal 1565-1770. Cliometrica, 11(3),

Ribeiro, Orlando (1986). Portugal, o Mediterrâneo e o Atlântico: Esboço de Relações Geográficas. Lisboa: Sá da Costa. 
Ridolfi, Leonardo (2016). The French economy in the longue durée. A study on real wages, working days and economic performance from Louis IX to the Revolution (1250-1789). IMT School for Advanced Studies Lucca

Rodrigues, Teresa Ferreira (ed.) (2008). História da população portuguesa: Das longas permanências à conquista da modernidade. Porto: Afrontamento.

Sá, Isabel (2005). O trabalho. In: Lains, Pedro and Silva, Álvaro (eds), História Económica de Portugal 1700-2000. O Século XVIII. Lisboa: ICS, vol. I, 93-121.

Santos, Rui (2003). Sociogénese do Latifundismo Moderno: Mercados, Crises e Mudança Social na Região de Évora, Séculos XVII a XIX. Lisboa: Banco de Portugal.

Schön, Lennart and Olle Krantz (2012). The Swedish economy in the early modern period: constructing historical national accounts. European Review of Economic History 16, 529549 .

Silva, Francisco Teixeira da (1861). Informações para a Estatística Industrial do Distrito de Coimbra. Lisboa: Imprensa Nacional.

Silva, Luis Rebello da (1868). Compêndio de Economia Rural. Lisboa: Imprensa Nacional.

Thomas, Richard and McCloskey, Deirdre (1981). Overseas trade and empire 1700-1800. In Roderick Floud and Deirdre McCloskey (eds), The Economic History of Britain since 1700. Cambridge: Cambridge University Press, vol. 1, 87-102.

Van Zanden, J. L. (2005). Una estimación del crescimiento economico en la edad moderna. Investigaciones de Historia Economica (1): pp. 9-38.

Van Zanden, J. L. (2009). The Long Road to the Industrial Revolution: The European Economy in a Global Perspective, 1000-1800. Leiden: Brill.

Van Zanden, Jan Luiten and Bas van Leeuwen (2012). Persistent but not consistent: The growth of national income in Holland 1347-1807. Explorations in Economic History 49, 119130 .

Viterbo, Fr. Joaquim (1983). Elucidário das palavras, termos e frases que em Portugal antigamente se usaram e que hoje regularmente se ignoram. Mário Fiúza (ed.). Porto: Civilização.

Wrigley, E. A. (1985). Urban growth and agricultural change: England and the Continent in the early modern period. Journal of Interdisciplinary History 15, 683-728.

Wrigley, E. A. and R. S. Schofield (2010/1989). The Population History of England 15411871. Cambridge: Cambridge University Press. New edition.

Wrigley, E. A., Davies, R. S., Oeppen, J. E. and R. S. Schofield (1997). English Population History from Family Reconstitution 1580-1837. Cambridge: Cambridge University Press. 


\title{
Appendix to \\ FROM CONVERGENCE TO DIVERGENCE: PORTUGUESE ECONOMIC GROWTH, 1527-1850
}

\author{
(FOR ONLINE PUBLICATION ONLY)
}

The data for this paper is available online at: [link to be added upon publication]

I - Percentage of the yearly variation of the principal data that is covered by our sources

\begin{tabular}{cccccccccccc}
\hline & $\begin{array}{c}\text { Unskilled } \\
\text { wages }\end{array}$ & $\begin{array}{c}\text { Skilled } \\
\text { wages }\end{array}$ & Wheat & Maize & Meat & Eggs & Chickens & Wine & $\begin{array}{c}\text { Olive } \\
\text { oil }\end{array}$ & Coal & Linen \\
\hline $\begin{array}{c}1527- \\
1600\end{array}$ & 80 & 85 & 92 & n.a. & 62 & 50 & 68 & 85 & 74 & 72 & 76 \\
\hline \begin{tabular}{c}
$17^{\text {th }} \mathrm{c}$. \\
\hline $18^{\text {th }} \mathrm{c}$.
\end{tabular} & 94 & 91 & 100 & 99 & 100 & 100 & 100 & 100 & 100 & 100 & 99 \\
\hline $\begin{array}{c}1801- \\
1850\end{array}$ & 100 & 100 & 100 & 100 & 100 & 100 & 100 & 100 & 100 & 100 & 83 \\
\hline
\end{tabular}

Table A1. Data coverage for the main variables underlying the construction of our series (\% covered by at least one of our four regions). Sources: PWR project.

\section{II - Primary data sources employed in this article}

All the primary sources consulted in gathering the data for this article are given, by region, in the references section below. Figure A1 is an example of how a typical page of the many account books we consulted for primary data looks like:

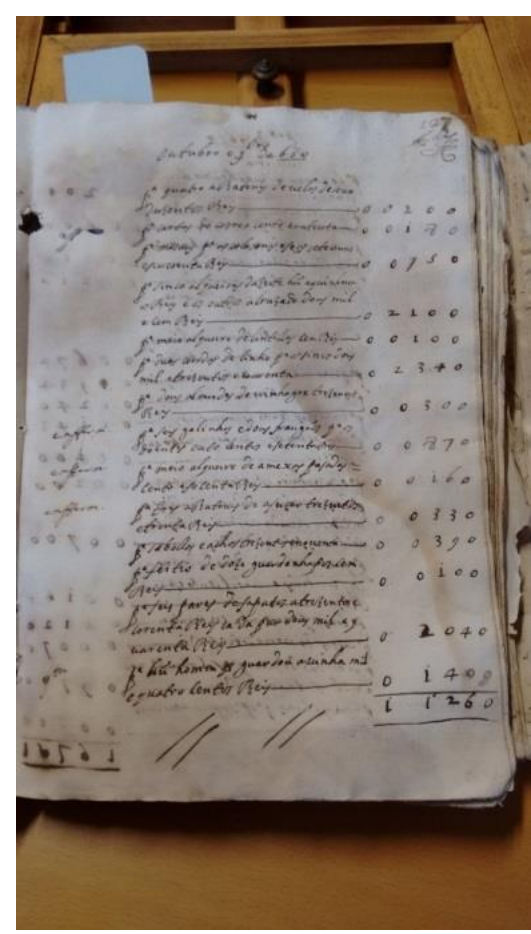

Figure A1. A typical example from an expenses book page containing wages and prices. 
$\underline{\text { III - Additional figures }}$

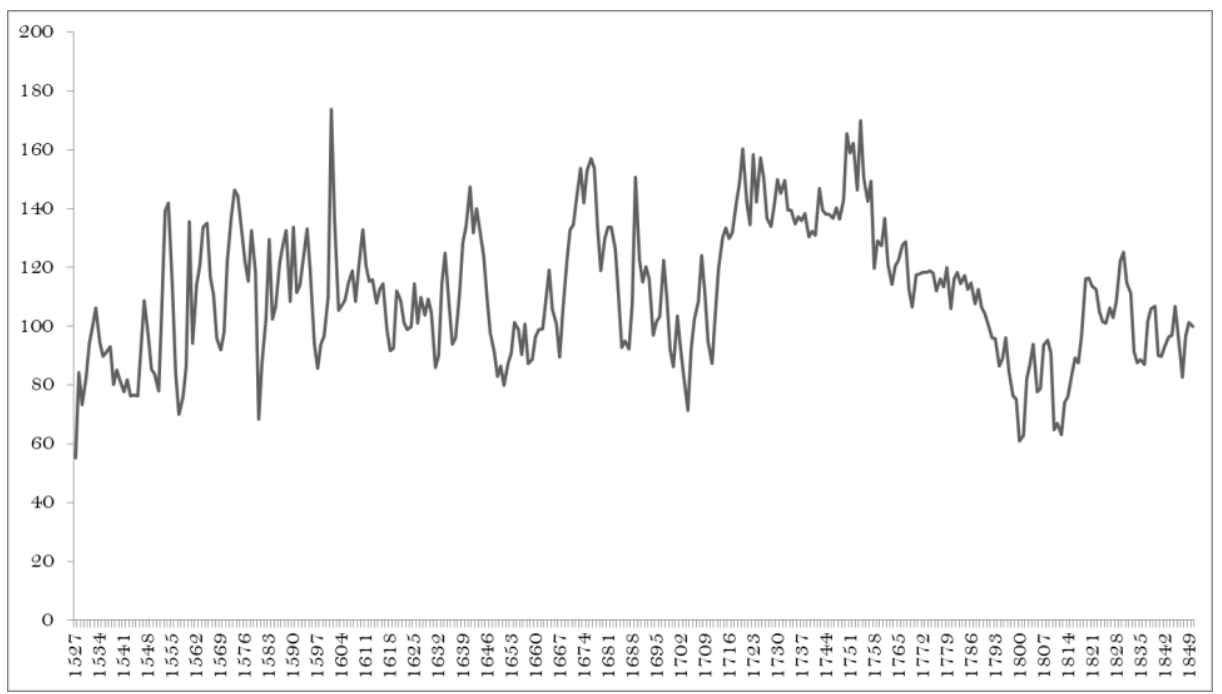

Figure A2. Lisbon real day wages for unskilled workers (index, 1850=100). Sources: see text.

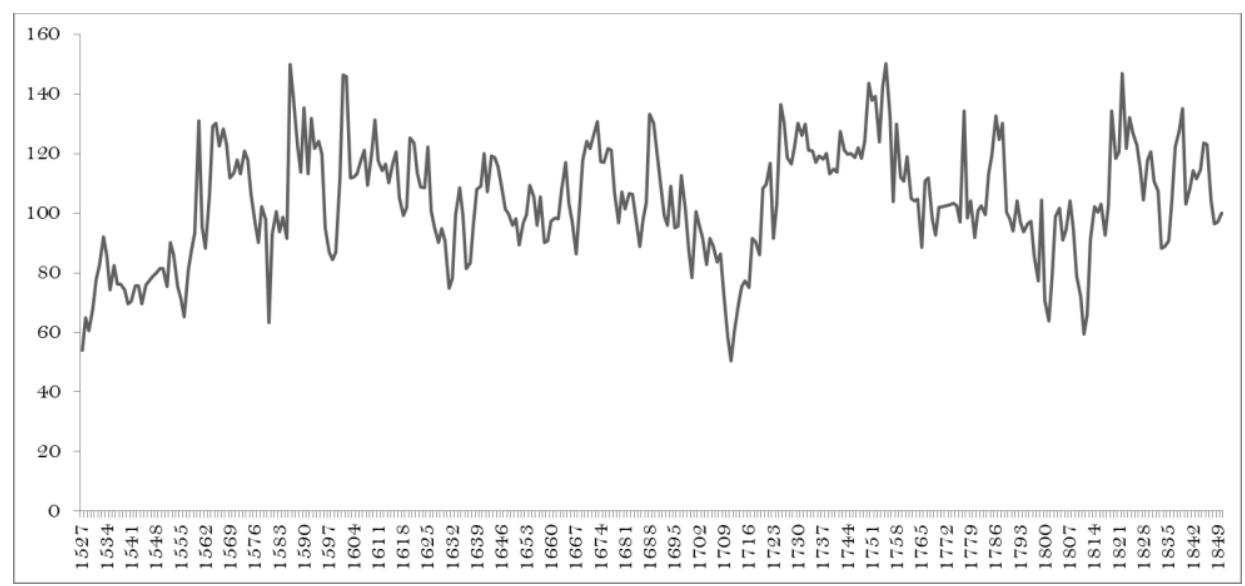

Figure A3. Lisbon real day wages for skilled workers (index, 1850=100). Sources: see text.

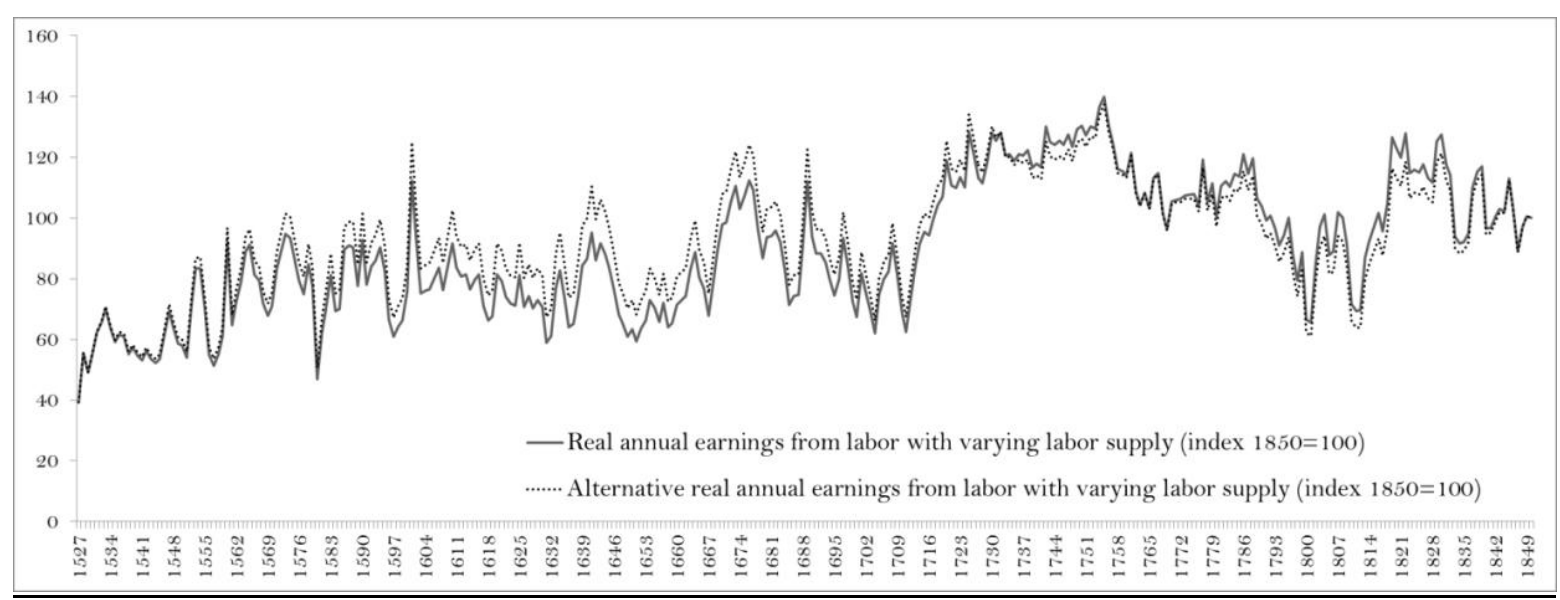

Figure A4. Lisbon's annual earnings per worker under alternative assumptions for days worked. The solid line shows our baseline real annual earnings compared with those with interpolated working days since the beginning of the sample. 


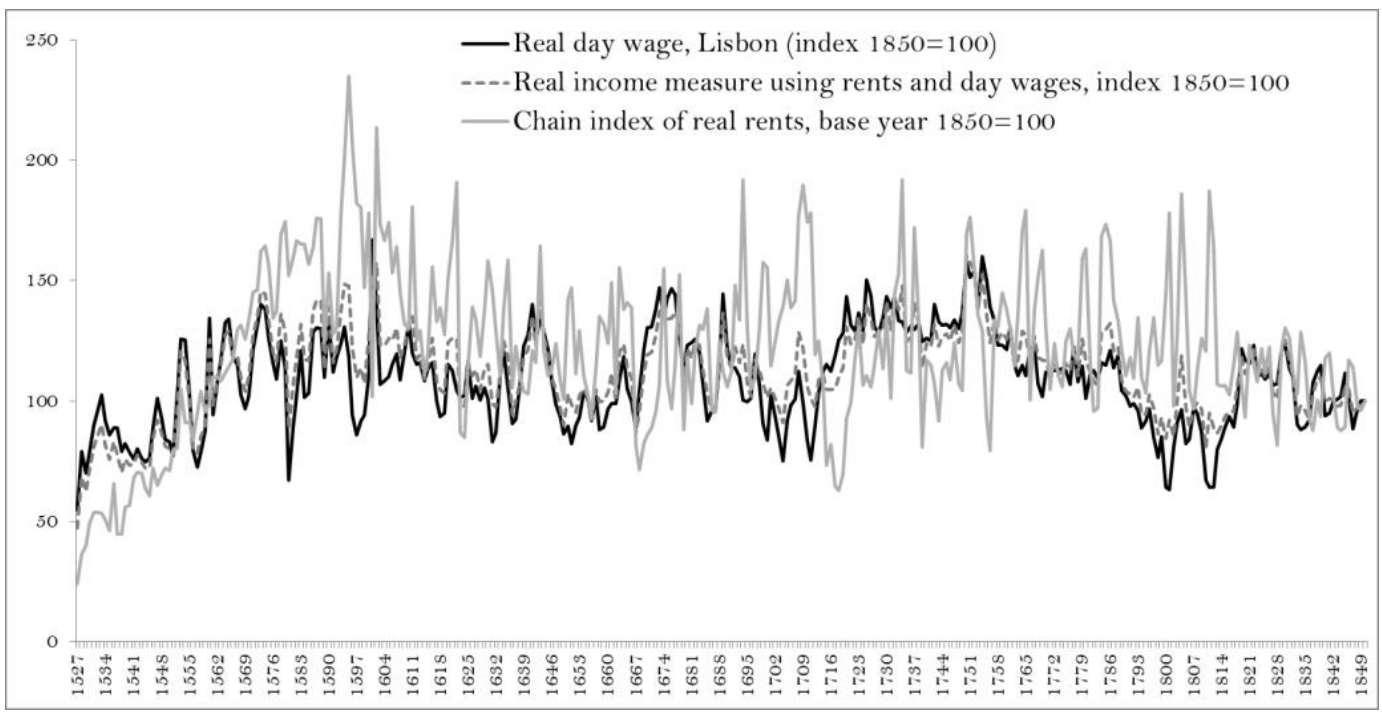

Figure A5. Land rents and real income (Lisbon's hinterland only) including and excluding land rents.

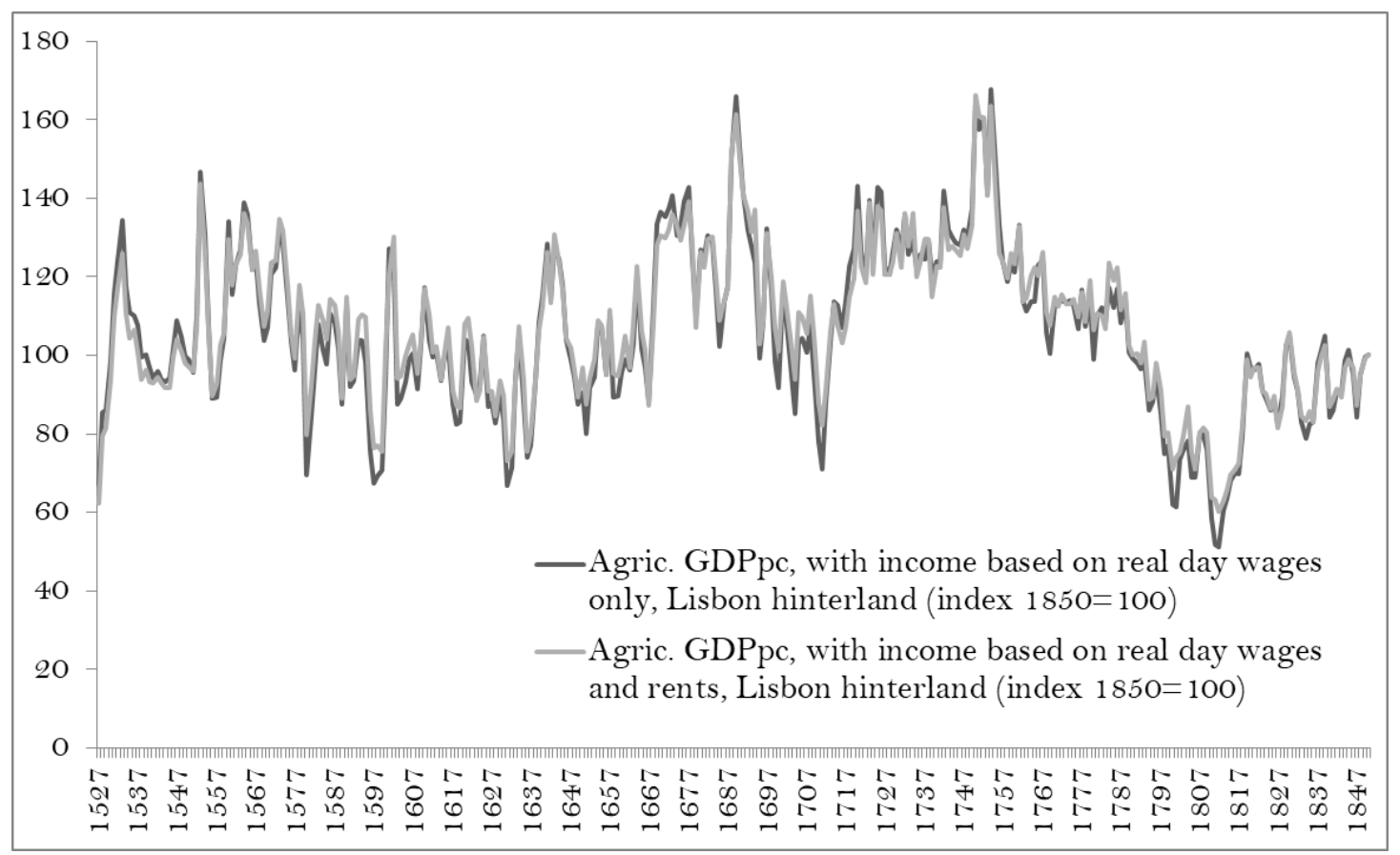

Figure A6. Agricultural GDP per capita based on Lisbon's day wages, with vs. without land rents. 


\section{$\underline{\text { IV - Portugal's external food balance }}$}

Table A2 shows the results. The Appendix to Costa and Reis (2016) gives the information on sources and how these figures were arrived at. For each benchmark, the export or import of the three main items of food trade, in their respective current values in grams of silver (cols.1, 2 and 3) is expressed and then summed up to obtain the overall food deficit or surplus in silver too (col.4).

\begin{tabular}{|c|c|c|c|c|c|c|c|}
\hline & (1) & (2) & (3) & (4) & (5) & (6) & $(7)$ \\
\hline & $\begin{array}{c}\text { Wine } \\
\text { exports }\end{array}$ & $\begin{array}{l}\text { Olive oil } \\
\text { exports }\end{array}$ & $\begin{array}{l}\text { Grain } \\
\text { imports }\end{array}$ & $\begin{array}{l}\text { Food sur- } \\
\text { plus/deficit }\end{array}$ & $\begin{array}{l}\text { Agricultural } \\
\text { consumption }\end{array}$ & $\begin{array}{l}\text { Surplus/deficit } \\
\text { /agricultural } \\
\text { consumption \% }\end{array}$ & $\begin{array}{l}\text { Food produc- } \\
\text { tion/ } \\
\text { consumption } \\
\text { ratio } \mathbf{r}\end{array}$ \\
\hline 1550 & - & 0.7 & 17.4 & -16.7 & 916.1 & -1.82 & 0.982 \\
\hline 1600 & 0.02 & 14.2 & 24.5 & -10.3 & 1965 & -0.005 & 0.995 \\
\hline 1650 & 0.9 & 18.5 & 14.3 & 5.1 & 1961 & 0.003 & 1.003 \\
\hline 1700 & 11.9 & 27.2 & 14.4 & 24.7 & 1858 & 1.3 & 1.013 \\
\hline 1750 & 14.9 & $15.6^{*}$ & 23.0 & 7.5 & 2311 & 0.3 & 1.003 \\
\hline 1800 & 128.5 & 8.3 & 151.6 & -14.8 & 3360 & -0.4 & 0.996 \\
\hline 1850 & 117.2 & 4.3 & 6.95 & 114.6 & 3742 & 3.1 & 1.031 \\
\hline
\end{tabular}

Table A2. Portugal's external food balance. Cols 1-5 in millions of grams of silver. * interpolated value based on average of quantities for 1700 and 1800 valued at 1750 prices. Source: Costa and Reis (2016)

Since we do not possess any quantification of national agricultural consumption at current prices, a short cut estimation method proposed by Malanima (2011, p. 179) is used instead. This procedure starts by multiplying the total wage bill in grams of silver by 1.4 which gives us the estimated income of all production factors (land, labor and capital). This is multiplied by a coefficient of 0.6, to arrive at a figure, also in silver, representing the total expenditure on food by the recipients of national income, i.e. the population (col.5). We can then determine the magnitude of the food surplus/deficit relative to food consumption (col 6 of table A2) and the value of the ratio $\mathbf{r}$ (col. 7 of table A2) which can be used to adjust correctly food consumption when trying to estimate agricultural output. 


\section{Appendix references}

\section{$\underline{\text { Primary sources }}$}

We have collected both prices and wages from account (receipts and expenditures) books of the institutions listed below. Almost all were purchasers both of commodities and labor services. Some of them were also sellers of certain commodities produced by them. The account books of these institutions always display: the date of the transaction, the gross and unit value of the commodity, the unit of measurement employed, the quality of the product (e.g. coarse or fine paper, mutton, pork or beef) and particular features of the transaction.

In order to proxy missing values we sometimes used a similar product or labor type (e.g. tallow candles for wax candles, or carpenters for masons, both being skilled workers) by adjusting its price using a price ratio with the original product at a nearby year. Furthermore, to complete our Linen series for Lisbon during 1766-1829, we relied on Madureira (1997), listed in the secondary sources section.

\section{Lisbon and its hinterland}

Casa da Congregação do Oratório (BPA) Casa da Saúde, L ${ }^{\circ} 1^{\circ}$ Receita e Despesa (AMLx)

Casa dos Contos: Archive of the Court of Auditors

Convent of Nossa Senhora da Luz: National Archive

Convent of Santa Marta de Jesus: National Archive

Convent of Santo Alberto: National Archive

Convent of São Domingos de Lisboa: National Archive

Convent of Carmo, Expenses of the Sacristy: National Archive

Hospital of S. José: National Archive

Hospital of All Saints: National Archive

Holy House of Mercy of Almada: ASCM Almada

Holy House of Mercy of Lisbon: Archive of the Holy House of Mercy of Lisbon

Holy House of Mercy of Lisbon, Shelter: Archive of the Holy House of Mercy of Lisbon

Holy House of Mercy of Lisbon, Foundlings: Archive of the Holy House of Mercy of Lisbon

Monastery of Chelas: National Archive

Monastery of S. Dinis de Odivelas: National Archive

Convent of Santo António da Convalescença: National Archive

Fabric of the See of Lisboa: National Archive

Seminary of Santa Catarina: National Archive

Administration of the Royal Household, Kitchens: National Archive

$\underline{\text { Porto and its hinterland }}$

For Porto, we rely on Godinho (1955) as a secondary source plus the following primary sources:

Casa Pia Orphanage (administration): Porto District Archive

The See of Porto (revenues and expenditure): Porto District Archive

Colégio dos Órfãos, Daily Expenditure: Porto Municipal Archive

Porto Holy House of Mercy, Jailhouse Expenditure: Archive of the Santa Casa da Misericórdia do Porto.

Porto Holy House of Mercy, General Hospital: Archive of the Santa Casa da Misericórdia do Porto.

Porto Holy House of Mercy, Interments: Archive of the Santa Casa da Misericórdia do Porto. 
Porto Holy House of Mercy, Hospice for the Homeless: Archive of the Santa Casa da Misericórdia do Porto

Porto Holy House of Mercy, D. Lopo Hospital: Archive of the Santa Casa da Misericórdia do Porto

Porto Holy House of Mercy, Foundling Home: Archive of the Santa Casa da Misericórdia do Porto

Municipality of Porto, Palace of the Municipality: Porto Municipal Archive Municipal Abattoir, Porto Municipality: Porto Municipal Archive

\section{$\underline{\text { Coimbra and its hinterland }}$}

University of Coimbra, Refectory: Archive of the University of Coimbra

Hospital of the University, Accounts and Administration: Archive of the University of Coimbra Hospital of Nossa Senhora da Conceição, Accounts: Archive of the University of Coimbra

College of São Pedro, Kitchen: Archive of the University of Coimbra

Colégio de São Pedro, Book of purchases: Archive of the University of Coimbra

Expenditure on the Churches of the Reverend Chapter of the See of Coimbra: Archive of the University of Coimbra

Chapel of S. João da Sé, Revenue and Expenditure: Archive of the University of Coimbra

Chapter of the See, register of expeditures: Archive of the University of Coimbra

Fabric of the College of São Pedro, Registo of Expenses : Archive of the University of Coimbra Municipal Council of Coimbra, Revenue and Expenditure: Archive of Coimbra

Municipality Works of the Church of the See of Coimbra, Expenses: Archive of the University of Coimbra

University of Coimbra, Receipts and Expenditure: Archive of the University of Coimbra

Hospital of São Lázaro, Receipts and Expenditure: Archive of the University of Coimbra

Holy House of Mercy of Coimbra, Income and Expenditure: Archive of the Holy House of Mercy of Coimbra

Episcopal Mitre of Coimbra, Expenses: Archive of the University of Coimbra

Register of the Granary of the Chapter of Coimbra: Archive of the University of Coimbra

Royal Hospital of Coimbra, Registers of Expenditure: Archive of the University of Coimbra

\section{$\underline{\text { Évora and its hinterland }}$}

For Évora, we rely on Santos (2003) and Godinho (nd) secondary sources plus the following primary sources:

Royal Public Granary of Évora, Accounts: Archive of the District of Évora

Évora Aqueduct, Accounts of the Repairs and Maintenance: Archive of the District of Évora Repairs of Évora City Streets, Wages and other Expenditure: Archive of the District of Évora Casa Pia Orphanage, Revenues and Expenditures: Archive of the District of Évora

Casa Pia, Hospice of Nossa Senhora da Piedade, Accounts: Archive of the District of Évora Holy House of Mercy, Books and Accounts: Archive of the District of Évora

Convent of Paraiso, Accounts: Archive of the District of Évora

Convent of the Saviour, Accounts: Archive of the District of Évora

College of Nossa Senhora da Purificação: Archive of the District of Évora

\section{Secondary sources}

Costa, Leonor and Jaime Reis (2016). The chronic food deficit of early modern Portugal: Curse or myth? Análise Social LII, 416-429. 
Godinho, Vitorino Magalhães (nd). Introdução à história económica. Lisboa: Livros Horizonte

Godinho, Vitorino Magalhães (1955). Prix et monnaies au Portugal 1750-1850. Paris: Livre Aurmant Colin

Madureira, Nuno (1997). Mercados e Privilégios. A Indústria Portuguesa entre 1750 e 1834. Lisboa: Estampa.

Santos, Rui (2003). Sociogénese do Latifundismo Moderno: Mercados, Crises e Mudança Social na Região de Évora, Séculos XVII a XIX. Lisboa: Banco de Portugal 